\title{
III Jornada de Iniciação Científica do INCA
}

DATA: 6 e 7 de julho de 2006

LOCAL: Instituto Nacional de Câncer

Auditório da Coordenação de Pesquisa

Rua André Cavalcanti, 37 / $1^{\circ}$ andar - Centro - Rio de Janeiro - RJ

\section{ORGANIZAÇÃO}

Adriana Bonomo - Organização e Coordenação do Programa de Iniciação Científica do INCA (PIC-INCA)

Claudia Alicia Esther Rocio Hassan - Coordenação Adjunta do PIC-INCA

Prof. Cristiano Gonçalves Ponte - Coordenação Adjunta do PIC-INCA

\section{COMISSÃO AVALIADORA}

Consultores externos:

Claudia Gallo - UERJ

Eleonara Kurtenbach - UFRJ

Eusenir Sarno - FIOCRUZ

Júlio Scharfstein - UFRJ

Marcello Pellajo - FIOCRUZ

Consultores internos:

Anke Bergman - HC III / INCA

Claudete Klumb - Hematologia / INCA

Luiz Claudio Thuler - CEDC / INCA

Mártin Bonomo - MEDEX / INCA

Rosane Vianna Jorge - Farmacologia / INCA

COLABORAÇÃO

Cecília Herculano Ferreira

Danielle Cristina da Silva Brito

DIVULGAÇÃO

Serviço de Divulgação Científica/CEDC/INCA

\section{OBJETIVOS}

- Divulgar os trabalhos realizados pelos estudantes de Iniciação Científica (IC) do Instituto Nacional de Câncer;

- Avaliar o Programa de IC do INCA. 


\section{O Programa de Iniciação Científica do INCA: nossa semente}

O Programa Iniciação Científica do INCA teve início no ano 2000, numa iniciativa da então Coordenadora de Ensino, Maria Alice Sigaud, juntamente com o Coordenador de Pesquisa da época, Guilherme Kurtz. Naquele momento, foram concedidas dez bolsas pelo Ministério da Saúde para a formação de estudantes de graduação, distribuídas por mérito entre os diversos solicitantes. Em 2003, o Professor Marcello A. Barcinski sugeriu que solicitássemos ao CNPq nossa inclusão no Programa Institucional de Bolsas de Iniciação Científica, PIBIC, um programa de concessão de bolsas de IC às instituições de ensino em pesquisa. Foram concedidas dez bolsas à nossa Instituição apesar da ausência de uma Pós-Graduação Stricto Sensu na época. Obviamente, nosso corpo de pesquisadores foi quem conseguiu a confiança do CNPq. O sucesso do programa foi tal que, em 2005, já contávamos com 20 bolsas do MS e, recebemos mais dez bolsas do CNPq perfazendo um total de 40 bolsas concedidas para estudantes de graduação que estagiavam em nossos laboratórios e serviços onde havia atividades de pesquisa.

A partir de 2003, foi criada a Jornada de Iniciação Científica do INCA onde os estudantes têm a oportunidade de apresentar seus trabalhos e discutirem seus dados com outros profissionais da área. A jornada, além de servir aos estudantes, é o nosso objeto de avaliação de desempenho do Programa de Iniciação Científica e conta com a participação de avaliadores internos e externos à Instituição. A qualidade dos trabalhos apresentados e o profissionalismo dos nossos estudantes têm surpreendido a todos, justificando o aumento do número de bolsas dados pelo CNPq à nossa Instituição.

Este ano, dez trabalhos foram apresentados oralmente e todos (41 no total) foram apresentados na forma de painéis. Desta forma, todos os estudantes tiveram a chance de conversar com seus pares, discutir seus resultados e experimentos, permitindo a divulgação das linhas de pesquisa e gerando novas colaboraçôes. Com o apoio das Coordenadoras de Pesquisa, Marisa Breitenbach, e de Ensino, Eliana Claudia Otero Ribeiro, foram concedidas viagens a congressos nacionais aos quatro melhores trabalhos selecionados pelo comitê avaliador que também receberam uma Menção Honrosa (vide abaixo os alunos e os títulos dos trabalhos premiados).

Para 2006/2007, o Programa de Iniciação Científica do INCA contará com cursos e seminários dirigidos para o ensino de pesquisa no nível da graduação. Pretendemos com isto contribuir para a formação de novos cientistas, reforçando o ensino de métodos e a metodologia da ciência, aumentando a interface de troca entre as diversas áreas.

A possibilidade de ter os resumos da III Jornada de Iniciação Científica do INCA publicados na Revista Brasileira de Cancerologia foi "uma porta aberta" pelo Dr. Luiz Claudio Thuler. Esta iniciativa, sem dúvida, incentiva os alunos, divulga e documenta nosso trabalho. Neste número, apresento ainda uma síntese da conferência de encerramento da jornada, proferida pela Professora Aniela Improta França, sobre as bases neurofisiológicas da linguagem, um assunto aparentemente desconectado do nosso campo de trabalho. A idéia é exatamente mostrar aos estudantes que a ciência boa requer a compreensão da metodologia científica. E quando isto é bem feito e além do mais com paixão, é sempre fascinante e enriquecedor. Além da conferência, destaco também a carta do Professor Erney Camargo, presidente do CNPq, dirigida aos coordenadores dos PIBIC onde, de forma muito clara, ele explica o que é e como deve ser tratada a iniciação científica. Finalmente, os dez trabalhos escolhidos pelos respectivos serviços ou divisões para serem apresentados oralmente foram publicados como resumos estendidos, representativos das diversas áreas de pesquisa do INCA.

A seguir, relaciono os trabalhos premiados e seus autores:

- Ana Cristina de Albuquerque Xavier, Trabalho: "Biogênese de autofagossomos em resposta à radiação em células de adenocarcinoma de cólon humano, HCT-116". Orientador: José Andrés Morgado Diaz.

- Marcela Braga Mansur, Trabalho: "Freqüência da fusão SIL-TAL1 em pacientes com leucemia linfoblástica aguda de linhagem T (LLA-T)". Orientadora: Maria do Socorro Pombo de Oliveira.

- Rafaela Fidelis Lima, Trabalho: "Regulação da atividade das células T pelo estroma de medula óssea". Orientadores: Adriana Bonomo e João Paulo B. Monteiro.

- Tatiana Martins Tilli, Trabalho: "Auto-anticorpos anti-osteopontina como potenciais marcadores séricos em neoplasias". Orientadora:. Etel Rodrigues Pereira Gimba. 


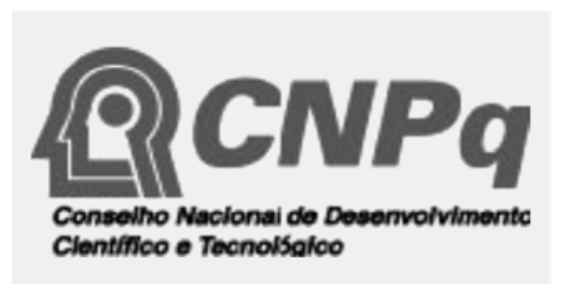

OF. Circ. PR. No 0137/06
Brasília, 22 de março de 2006.

Prezados (as) Coordenadores (as) do PIBIC,

Estamos próximos de iniciar mais uma etapa referente às atividades do Programa Institucional de Bolsas de Iniciação Científica (PIBIC), período 2006/2007.

É fundamental reiterar a decisão do Conselho Deliberativo (CD) do CNPq no sentido de esclarecer alguns aspectos dos Programas de Iniciação Científica do Conselho.

O CD considera a Iniciação Cientifica (IC) um poderoso instrumento de divulgação dos métodos e princípios da ciência e um dos mais importantes programas do CNPq. Seu público alvo são os estudantes de graduação dos cursos superiores de instituiçōes públicas ou privadas. Seu modo de atuação implica o convite a estudantes para se associarem a pesquisadores ou grupos de pesquisa de instituições credenciadas.

O CD considera a IC um programa voltado para o aluno, não para o pesquisador. A IC se destina a complementar o ensino de graduação oferecendo a milhares de alunos a oportunidade de descobrir como a ciência é produzida, como o conhecimento é adquirido. Esse objetivo é conseguido pela participação do aluno nas atividades práticas e teóricas no ambiente de pesquisa. $\mathrm{O} C D$ acredita que essa vivência ajudará o aluno a ver e entender o mundo sob o prisma da ciência. A IC é, em essência, um programa de desmistificação cultural, avesso a dogmas, destinado a esclarecer e completar a formação intelectual dos alunos.

Embora os alunos devam participar de pesquisa do grupo a que estão ligados e nele assumir tarefas específicas, em nenhuma hipótese a IC pode ser tratada como um programa destinado a prover mão-de-obra para pesquisadores ou grupos de pesquisa. O sentido é contrário: é o pesquisador e o seu grupo que devem dedicar parte de seu tempo ao ensino prático e conceitual da pesquisa ao aluno de graduação. Portanto, quanto mais dedicados, mais bem capacitados e mais experientes forem os pesquisadores, melhor para o aluno. Não será o aluno de IC quem irá fortalecer ou ajudar a desenvolver grupos de pesquisa. Esse é um conceito absolutamente equivocado. Pelo contrário, grupos bem formados de pesquisa é que poderão desenvolver o aluno.

Nesse sentido, o CD pede aos dirigentes institucionais e pesquisadores que zelem pelo cumprimento dos objetivos e diretrizes da Iniciação Cientifica, em qualquer de suas modalidades programáticas: institucional (PIBIC) ou individual (IC).

Atenciosamente,

ERNEY PLESSMANN CAMARGO

Presidente

Ministério da Ciência e Tecnologia
Conselho Nacional de Desenvolvimento

Científico e Tecnológico

Gabinete da Presidência

SEPN 507, Bloco B, $3^{\circ}$ andar, Ed. Sede CNPq

70740-901 Brasília DF Brasil
Telefone +55613489421

Fax +55 613489487

e-mail:presidencia@cnpq.br 


\title{
A epistemologia lingüística e a neurofisiologia da linguagem
}

\author{
Aniela Improta França ${ }^{1}$
}

Entre os lingüistas, uma queixa freqüente é a de que a lingüística como tópico de estudo não é bem compreendida pelas pessoas, pela mídia e tampouco por outras ciências. Não, não estudamos literatura, sotaques, gramáticas prescritivas do discurso, do bom falar ou do escrever. Não, as crianças não aprendem a falar com seus pais, através de repetições de falas simplificadas. A linguagem cresce na mente do bebê através de um programa genético assim como outras cogniçóes: visão, teoria da mente de outros, navegação, conceito de numerosidade etc. Portanto, o estudo da cognição de linguagem, a Lingüística, não deveria ser agrupado pelas agências de fomento com a música, literatura, arquitetura e arte. Somos biologia, neurociência básica porque estudamos cognição que tem residência no cérebro humano.

E a insatisfação neste departamento de public relations é unânime na nossa classe no Brasil e no exterior. Ainda assim, nunca tinha ouvido ou eu mesma nunca havia conseguido esboçar a razão deste engano de senso comum sobre a epistemologia da lingüística. Até que, em maio de 2006, convidamos um jovem pesquisador de Harvard - Andrew Nevins - para uma série de palestras no Departamento de Lingüística da UFRJ. Andrew Nevins, que eu saiba, foi a primeira pessoa que identificou o porquê deste desentendimento: Ele explicou que só seríamos agrupados com a física e a biologia se pudéssemos mostrar aos nossos interlocutores que a Faculdade de Linguagem é regida por leis invioláveis, assim como a lei da gravidade, ponto de ebulição, valência atômica etc.

$\mathrm{Na}$ arte, as leis são sempre violáveis. Se bem no final do século XIX o estilo de época era o neoplasticismo, que aboliu a figura humana em prol das formas e cores puras como em Mondrian, logo no primeiro decênio do séc XX surge o cubismo de Picasso que viola solenemente o neoplasticismo e reintroduz a figura humana concebida em cubos. $\mathrm{Na}$ sociedade, também existem leis contra o adultério, contra o aborto, contra o homicídio, contra o roubo, mas elas certamente são violáveis independentemente das conseqüências.

Pois bem: "existe uma parte muito visível da lingüística que é aparentemente violável", diz o Andrew . É notável que há variaçôes entre falantes nativos: Quatro menino, quatro meninos; para mim fazer, para eu fazer; a maioria das pessoas é, a maioria das pessoas são, É preciso que eu vá, É preciso eu vá. Oops, não aqui. Esta pequena conjunção, só três letrinhas, q-u-e, não pode deixar de existir pois sem ela uma sentença não pode ser encaixada dentro da outra.

Então há leis lingüísticas invioláveis sob pena de fazer um falante nativo soar como um gringo. Poderíamos concluir que as tais leis violáveis da lingüística, por exemplo a concordância de plural, não são propriamente leis; são opçôes lícitas, tecnicamente chamadas de parâmetros. Estes diferem das leis inescapáveis, tecnicamente chamadas de princípios, como o uso de conjunção em português para encaixe de oração subordinada.

A idéia de que ao nascermos portamos princípios lingüísticos, ou seja, conhecimento lingüístico embrionário para o desenvolvimento de qualquer língua, e que esses princípios se fixam em parâmetros que se especificam para a língua-mãe do aprendiz por meio da exposição aos dados primários (dados lingüísticos ao natural oriundos do entorno da criança), foi formulada pelo lingüista do MIT, Noam Chomsky, no programa de estudos chamado de Programa de Princípios e Parâmetros:

${ }^{1}$ Professora Adjunta de Lingüística do Departamento de Lingüística da UFRJ. Membro do Programa Avançado de Neurociências (PAN) da Faculdade de Medicina da UFRJ. 
"Podemos comparar o estado inicial da faculdade de linguagem com uma fiação fixa conectada a uma caixa de interruptores; a fiação são os princípios da linguagem, e os interruptores são as opções a serem determinadas pela experiência. Quando os interruptores estão posicionados de um modo, temos o bantu; quando estão posicionados de outro modo, temos o japonês. Cada uma das línguas humanas possíveis é identificada como uma colocação particular das tomadas - uma fixação de parâmetros, em terminologia técnica. Se esta abordagem de pesquisa der certo, deveríamos poder literalmente deduzir o bantu de uma escolha dos posicionamentos, o japonês de outra e assim por diante por todas as línguas que os seres humanos podem adquirir. As condiçôes empíricas em que se dá a aquisição de língua requerem que os interruptores sejam posicionados com base na informação muito limitada que está disponível para a criança. Notem que pequenas mudanças em posicionamento de interruptores podem conduzir a uma grande variedade aparente em termos de output, pela proliferação dos efeitos pelo sistema. Estas são as propriedades gerais da linguagem que qualquer teoria genuína precisa captar de algum modo." (CHOMSKY, 1998, p. 23)

Então, voltando à idéia do Andrew Nevins, sendo os parâmetros mais visíveis na produção dos falantes do que os princípios, o senso comum aposta na violabilidade das leis da lingüística e classifica o fenômeno lingüístico como do tipo social. Bingo! Um mistério a menos no mundo.

Resta-nos agora divulgar este raciocínio, além de dar continuidade às pesquisas sobre a neurofisiologia da linguagem em indivíduos sãos. Este campo de estudos surgiu nos anos 90 e é eminentemente interdisciplinar, incluindo necessariamente a lingüística, a neurologia, a biologia e a engenharia biomédica. Assim, vamos pouco a pouco ganhando espaço entre as ciências biológicas.

Vale dizer que o conhecimento sobre a Faculdade de Linguagem antes dos anos 90 era gerado quase que exclusivamente pelo exercício de introspecção do lingüista sobre a sua própria competência de falante nativo. Aliás, esta prática de pensar com método sobre a própria fala é válida e construiu um entendimento sofisticado sobre a Faculdade de Linguagem no homem. Por exemplo, nos anos 50, Chomsky fez uma análise introspectiva das computações que necessariamente estariam envolvidas nas sentenças com verbos transitivos diretos, como quebrar nas sentenças (1) e (2):

(1) O menino quebrou o vaso.

(2) O menino quebrou a perna.

Examinando o vaso e a perna, que são objetos diretos (complementos) do verbo quebrar, Chomsky percebeu que as funçôes semânticas destes complementos, tecnicamente chamadas de papéis temáticos, são definidas pelo verbo. O verbo quebrar especifica que seu complemento será interpretado como algo que muda de estado íntegro para quebrado. Os complementos o vaso e a perna se prestam para satisfazer esta exigência do verbo, pois representam objetos físicos que podem facilmente passar por esta mudança. E ainda que tivéssemos complementos menos apropriados para assumirem este papel temático, faríamos manobras de ajuste coercitivo para encaixar a semântica do complemento a esta "camisa de força" de significado imposta por cada acepção do verbo². Assim,

\section{(3) João quebrou o meu dia.}

encontra alguma interpretação semântica compatível com as necessidades eventivas do verbo quebrar, do tipo João fez com que o meu dia, que seria inteiramente dedicado a uma certa atividade $\mathrm{A}$, fosse dividido entre a atividade $\mathrm{A}$, que provavelmente seria mais importante, e a atividade $\mathrm{B}$, que não me agrada tanto.

Mas, faça agora uma introspecção e veja se esta imposição do verbo em relação ao complemento também se estende a o menino, sujeito das frases (1) e (2). É bastante fácil perceber que em (1) a expressão o menino se refere à pessoa que executa a ação de quebrar, e por isso dizemos que tem o papel temático de agente. Contrastivamente, em (2) essa expressão se refere à entidade que é paciente da ação, e por isso ganha o papel temático de paciente.

\footnotetext{
${ }^{2}$ Note que no caso de um verbo transitivo ter mais de uma acepção, como em (a) Ela assinou o Globo, e (b) Ela assinou a carta, cada leitura do verbo impóe seu próprio papel temático. Assinar na acepção de "obter a assinatura de um periódico" impóe ao argumento interno, o periódico, o papel temático de "lugar de onde" , isto é, a partir de onde a assinatura inscrita autoriza a entrega do periódico a quem depositou a assinatura, enquanto assinar na acepção de "escrever o próprio nome em" impõe o papel temático de "lugar onde", ou seja, lugar onde a assinatura foi inscrita.
} 
E assim, a análise se aprofunda: Se (1) e (2) são exatamente iguais até a chegada do objeto direto, podemos supor que o que define o papel temático do sujeito o menino é a informação semântica que está no complexo verbo-objeto.

A conseqüência espetacular destas simples observaçōes de Chomsky é que, independentemente da ordem básica dos constituintes da sentença em uma dada língua - SVO, (sujeito, verbo, objeto) como no português; VSO, como no Árabe; VOS, como em Malagasi, OSV, como Xavante - para gerar ou processar uma sentença, primeiro fazemos a concatenação verbo-objeto (VO) e só depois concatenamos o sujeito ao composto VO. Este mecanismo de geração de sentenças é conhecido como derivação no sentido bottom-up, ou seja, de baixo para cima se considerarmos uma estrutura representacional em forma de árvore, ou da direita para a esquerda, se pensarmos na ordem da escrita das línguas ocidentais, por exemplo.

Então, nas línguas em que a ordem linear é SVO, como o português, para podermos interpretar semanticamente o sujeito de uma sentença, temos que computá-lo e guardá-lo na memória de trabalho, para depois juntá-lo ao composto verbo-objeto, que vai definir seu papel temático.

$\mathrm{Na}$ Lingüística, a informação de que o curso da derivação sintática é bottom-up, observada a partir de um vasto número de línguas, já está disponível há meio século. As evidências neurofisiológicas demoraram um pouco mais a chegar e vieram no bojo de uma literatura especializada que começou a se formar nos Estados Unidos e Europa a partir dos anos 90.

Em grande parte, são estudos que utilizam a técnica de extração de potenciais relacionados a eventos lingüísticos (ERP) para analisar a concatenação de verbo-objeto. Manipulações de congruência nessa concatenação, do tipo João esticou a geladeira, foram amplamente relacionadas a maiores amplitudes de um potencial negativo aos 400 ms pós-estimulo - o N400.

Aqui no Brasil, esse tipo de pesquisa com indivíduos sãos não havia sido realizada até 2002, quando conseguimos aplicar os experimentos neurolingüísticos que foram objetos da minha tese de Doutorado - Concatenações Lingüísticas: Estudo de diferentes módulos cognitivos na aquisição e no córtex (França, 2002). Essa pesquisa foi o resultado de um esforço conjunto do Departamento de Lingüística da UFRJ, através da Professora Miriam Lemle, orientadora da tese, e do Laboratório de Processamento de Sinais (Programa de Engenharia Biomédica da COPPE/UFRJ), por meio da equipe do Professor Antonio Fernando Catelli Infantosi.

O objetivo desse trabalho era investigar a reação cortical à incongruência na concatenação verbo-complemento em português. Logo, seguimos o protocolo clássico de experimentos para extração de N400, que consiste em apresentar ao voluntário, na tela de um computador, sentenças congruentes, como A menina leu um livro, misturadas aleatoriamente a sentenças incongruentes, do tipo $\mathrm{O}$ homem comeu uma sandália.

Além de testarmos na Série 1 estímulos clássicos para a elicitação do N400, onde verbo e complemento aparecem lado a lado (congruente: comer o bife; incongruente: matar o vento), incluímos outras duas séries de estímulos muito menos freqüentemente testados, que alteravam de forma sutil o contexto das incongruências. Queríamos saber se a "assinatura elétrica da incongruência" seria afetada por essas condições especiais dos estímulos.

Tabela 1. Exemplos de estímulos das Séries 1, 2 e 3

\begin{tabular}{|c|c|c|}
\hline Séries & Sentenças Congruentes & Sentenças Incongruentes \\
\hline 1. & A menina comeu o bife & O leão matou o vento \\
\hline 2. & $\begin{array}{l}\text { Lúcia ia limpar a cadeira } \\
\text { e também guardá-la }\end{array}$ & $\begin{array}{l}\text { João está segurando o bife } \\
\text { e quer lê-lo }\end{array}$ \\
\hline 3. & $\begin{array}{l}\text { Quais músicas Vera } \\
\text { compôs? }\end{array}$ & $\begin{array}{l}\text { Que histórias Denise } \\
\text { refogou? }\end{array}$ \\
\hline
\end{tabular}

A partir da Tabela 1, note que os verbos guardar e ler na Série 2 estão concatenados aos seus respectivos complementos em forma de pronome: la e lo. Como la e lo não têm conteúdos semânticos próprios, para sabermos se a concatenação deu certo temos que transferir para eles as características semânticas dos seus respectivos antecedentes, cadeira e bife. Guardar a cadeira faz sentido, mas ler o bife não. Será que essa incongruência também resulta em um N400? E será ele igual ao da Série 1? 
A Série 3 continha sentenças com sintagma QU-. Testamos, por exemplo, Quais músicas Vera compôs? e Que histórias Denise refogou? Repare que o sintagma QU- quais músicas completa o sentido do verbo compôs e, portanto, é interpretado ao lado desse verbo: Vera compôs quais músicas? Só que, nesse tipo de construção, o sintagma QUgeralmente aparece no início da sentença, deslocado de seu lugar de interpretação, como um recurso discursivo para avisar ao interlocutor que vem uma pergunta.

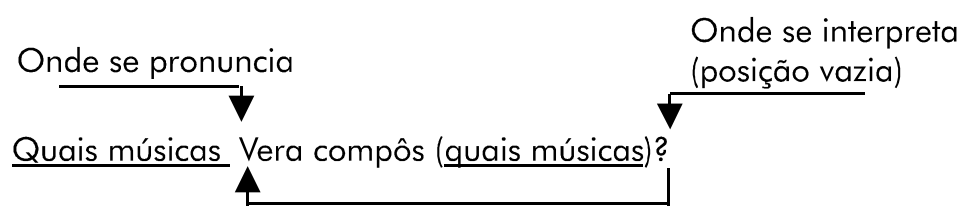

Os achados desse experimento indicam ERP contrastantes nas Séries 1,2, e 3. A forma díspar dos ERP deixa claro que concatenação verbo-complemento não é uma operação indivisa, ou seja, é formada por sub-tarefas. Há diversas formas do ERP N400 relacionadas às diferentes configuraçōes morfo-sintáticas das concatenações entre verbo e complemento. Esse achado é consistente com premissas de modelos da neurofisiologia da linguagem que vêem o processamento como a interação de micro-computações tarefa-específicas (Chomsky, 2001; Hauser, Chomsky, Fitch, 2002; França, 2004), plausivelmente envolvendo sub-sistemas neuronais e modos de acionamentos neuronais diferentes (Hickok, Poeppel, 2000, 2004; Poeppel, Marantz, 2000).

Além da cognição de verbo-objeto, tivemos aqui no Brasil uma primeira evidência neurofisiológica do curso derivacional bottom-up a partir de Lage (2005), uma tese de Doutoramento, orientada pelos Professores Miriam Lemle, do Departamento de Lingüística da UFRJ, e Antonio Fernando Catelli Infantosi, do Programa de Engenharia Biomédica da COPPE/UFRJ. Essa tese é intitulada Aspectos neurofisiológicos de concatenação e idiomaticidade em português do Brasil: um estudo de potenciais bioelétricos relacionados a eventos lingüísticos (ERP) e foi indicada pela Faculdade de Letras da UFRJ para concorrer ao Prêmio CAPES de Teses 2006.

No experimento principal, foi utilizada a técnica de extração de potencial relacionado a evento (event-related brain potential). O EEG bruto de voluntários era extraído, enquanto eles eram estimulados lingüisticamente, através da apresentação de sentenças na tela do computador, palavra por palavra. Cada palavra permanecia na tela por $200 \mathrm{~ms}$, e ao final da sentença era pedido que o voluntário opinasse, através do acionamento de um botão, se a sentença era congruente ou incongruente. A autora manipulou a congruência de sujeitos em sentenças dos tipos que se seguem, estabelecendo como tempo zero (gatilho para a aquisição dos sinais), o início da apresentação do nome que é complemento do verbo:

(4) A cadeira chutou a bola.

(5) O menino chutou a bola.

gatilho para a aquisição dos sinais: início do núcleo do complemento

Os traçados dos ERP extraídos do EEG mostraram ondas negativas aos $450 \mathrm{~ms}$. Essas ondas correspondem à concatenação verbo-objeto, chutou a bola, e são compatíveis com os achados clássicos na literatura de N400. Como em (4) e em (5) esta concatenação é congruente, as respostas corticais foram negatividades com elevação discreta.

Porém, aproximadamente aos $700 \mathrm{~ms}$, surgem outras negatividades. Estas ondas tinham amplitude muito maior quando provenientes de sentenças incongruentes como em (4), ou seja, aquelas em que a escolha do sujeito que não satisfaz exigências semânticas do predicado torna a sentença incongruente. Assim, a computação tardia do sujeito, há 50 anos já descrita por Chomsky, pôde ser revelada eletrofisiologicamente: um N700, sensível à incongruência e subseqüente ao N400 da concatenação verbo-objeto.

Além da confirmação neurofisiológica do curso das computaçōes lingüísticas, Lage (2005) traz uma novidade. Aos $200 \mathrm{~ms}$ após a exibição do objeto, aparecem ondas negativas com maior amplitude quando decorrentes de frases incongruentes. A autora interpreta esta negatividade aos $200 \mathrm{~ms}$ como uma compatibilização semântica precária entre a semântica do sujeito e a do verbo. Isto acontece porque, para que possa ser guardado na memória de trabalho, o sujeito é acessado em seus traços semânticos mais primitivos. E, a partir destes traços, já existe uma 
tentativa de compatibilização semântica com o verbo. Mas a computação da integração sintática só acontece depois, aos 700 ms. Ou seja, a autora pôde observar efeitos sutis de dois estágios da integração do sujeito.

Concluo com estes exemplos, agradecendo muitíssimo a oportunidade que a Adriana Bonomo deu a mim de aproximar a lingüística e a neurociência da linguagem de uma platéia da imunologia que reafirmo ser surpreendentemente mais próxima de nós do que se poderia pensar. Recentemente, ouvi em uma entrevista o Dr. Nelson Monteiro Vaz, imunologista da Universidade Federal de Minas Gerais dizer literalmente que "a atividade imunológica é uma atividade cognitiva de reconhecer o que é estranho e poder eliminar o que é estranho e poder guardar na memória para agir mais rapidamente da próxima vez." Para mim, esta descrição soou muito familiar.

\section{REFERÊNCIAS BIBLIOGRÁFICAS}

1. Rosa Luiz Pinguelli, Lemle Miriam. Noam Chomsky na UFRJ. Rio de Janeiro: COPPE/UFRJ; 1998. 145 p.

Chomsky, Noam. Beyond explanatory adequacy. Cambridge: Massachusetts Institute of Technology; 2001. MIT Occasional Papers in Linguistics.

2. França Aniela I. Concatenaçôes lingüísticas: estudo de diferentes módulos cognitivos na aquisição e no córtex [dissertação]. Rio de Janeiro: Universidade Federal do Rio de Janeiro; 2002.

3. França Aniela I, Lemle Miriam, Cagy Mauricio. Discriminating among different types of verb-complement merge in Brazilian Portuguese: an ERP study of morpho-syntactic sub-processes. J Neurolinguist. 2004;17:425-37.

4. Hauser Marc D, Chomsky Noam, Fitch W Tecumseh. The faculty of language: what is it, who has it, and how did it evolve? Science. $2002 ; 298: 1569-79$.

5. Hickok Gregory. Functional anatomy of speech perception and speech production: psycholinguistic implications. J Psycholinguist Res. 2001;30(3):225-35.

6. Hickok Gregory, Poeppel David. Dorsal and ventral streams: a framework for understanding aspects of the functional anatomy of language. Cognition. 2004;92(1-2):67-99.

7. _. Towards a functional neuroanatomy of speech perception. Trends Cogn Sci. 2000;4(4):131-8.

8. Lage Aleria C. Aspectos neurofisiológicos de concatenação e idiomaticidade em português do Brasil: um estudo de potenciais bioelétricos relacionados a eventos lingüísticos [tese].Rio de Janeiro: Universidade Federal do Rio de Janeiro; 2005.

9. Poeppel David, Marantz Alec. Cognitive neuroscience of speech processing. In: Marantz Alec, Miyashita Yasushi, O'neil Wayne, editors. Image, language, brain: papers from the first mind articulation project symposium. 2 nd ed. Cambridge: The MIT Press; 2000. p. 29-50. 


\title{
Implantação do teste de detecção da expressão e atividade da proteína BCRP nas leucemias
}

\author{
Gavinho-Vianna FA, Vasconcelos FC, Maia RC \\ Laboratório de Hematologia Celular e Molecular, Serviço de Hematologia, HCI/INCA
}

Introdução: Resistência a múltiplas drogas (MDR) é o principal obstáculo para o sucesso do tratamento e cura das leucemias. Esse fenômeno é mediado por proteínas transportadoras pertencentes à família $\mathrm{ABC}$ : glicoproteína $\mathrm{P}$ (Pgp), proteína relacionada à MDR (MRP) e a proteína relacionada ao câncer da mama (BCRP). A superexpressão das proteínas MDR são capazes de expelirem quimioterápicos para o exterior, reduzindo os seus conteúdos no interior das células leucêmicas tornando os pacientes resistentes ao tratamento. Diversos estudos têm demonstrado que a Pgp e a MRP afetam a taxa de remissão completa e sobrevida em pacientes com leucemia aguda. Entretanto, o papel da proteína BCRP, como fator prognóstico nas leucemias, não está completamente definido, assim como também o melhor método para a sua detecção. Objetivo: Padronizar e implantar o teste de detecção da expressão e atividade da proteína BCRP em células leucêmicas. Metodologia: Como controle positivo para a expressão da proteína BCRP, utilizou-se a linhagem celular MCF7 (proveniente de um câncer da mama metastático humano), que possui diferentes níveis de expressão e de resistência, obtidos através da exposição contínua e crescente de flavoperidol (FLV): MCF7 FLV 250, MCF7 FLV 500 e MCF7 FLV 1000. Após a padronização com as linhagens, foram estudadas amostras de medula óssea ou de sangue periférico de 49 pacientes com diferentes tipos de leucemias, por ocasião do diagnóstico ou da recaída. A expressão da BCRP foi detectada após a marcação com anticorpo monoclonal anti-BCRP. A atividade da proteína foi verificada mediante incubação das células com o fluorocromo pheophorbide associado ou não ao modulador fumitremorgim-C e analisadas em citômetro de fluxo. Os resultados obtidos foram expressos como a razão da intensidade de fluorescência (RIF). Resultados: Através da análise em Western blot e citometria de fluxo, observou-se que quanto maior a concentração de FLV maior a expressão da proteína BCRP nas linhagens. A linhagem MCF7, sensível, utilizada como controle negativo, exibiu $\mathrm{RIF}=1,14$ nos ensaios de expressão e RIF= 1,20 para a atividade da BCRP. A linhagem MCF7 FLV 500, resistente, apresentou níveis maiores de expressão $(\mathrm{RIF}=2,55)$ e de atividade $(\mathrm{RIF}=2,71)$ quando comparados à linhagem sensível. No grupo de pacientes estudados, observou-se expressão da proteína BCRP em 07/25 amostras de leucemia mielóide crônica, 03/13 amostras de leucemia mielóide aguda e 03/11 amostras de leucemia linfóide aguda. A atividade da proteína foi observada em $03 / 25$ amostras de leucemia mielóide crônica, 01/13 de leucemia mielóide aguda e 03/11 de leucemia linfóide aguda. Não houve correlação entre a atividade e a expressão da proteína BCRP nas amostras leucêmicas dos pacientes, isto sendo observado em apenas uma amostra de leucemia linfóide aguda. Discussão e conclusão: Os resultados obtidos com as linhagens, mostrando que houve correlação entre a expressão e atividade da BCRP, demonstraram que a metodologia empregada foi adequada e permite a padronização e a implantação da técnica para a detecção dessa proteína em linhagens celulares. Entretanto, o pequeno percentual de positividade observado no estudo de funcionalidade da BCRP, incluindo os pacientes refratários à quimioterapia, sugere que essa proteína possivelmente tem um papel menos importante relacionado à resistência aos quimioterápicos. A discrepância observada entre expressão e atividade da BCRP indica que novas metodologias devem ser empregadas para a melhor compreensão clínica do mecanismo de resistência às drogas mediada pela BCRP.

Apoio Financeiro: Swiss Bridge Foundation, FAPERJ, PRONEX. E-mail: hemato_hc@inca.gov.br 


\title{
Estudo do polimorfismo dos éxons 12 e 26 do gene MDR1 em indivíduos saudáveis brasileiros
}

\author{
Damasceno AM, Scheiner M, Klumb CG, Maia RC \\ Laboratório de Hematologia Celular e Molecular, Serviço de Hematologia, HCI/INCA
}

\begin{abstract}
Introdução: $\mathrm{O}$ gene MDR1 codifica a glicoproteína P (Pgp), uma bomba de efluxo que reduz a concentração de quimioterápicos no interior da célula, conferindo refratariedade ao tratamento. Sabe-se que os éxons 12, 21 e 26 do gene MDR1 são os mais importantes para estudos de polimorfismo. Sendo assim, torna-se necessário estudar se existe uma variação desse polimorfismo na população brasileira. Objetivo: Verificar a freqüência do polimorfismo dos éxons 12 e 26 do gene MDR1 em indivíduos saudáveis e comparar os resultados da literatura. Metodologia: Foram obtidas amostras de sangue periférico de 100 doadores de sangue do INCA. Desses, 60 doadores foram identificados quanto à cor em brancos, negros e intermediários (mulatos). Foram colhidos $10 \mathrm{ml}$ de sangue periférico e retirados os leucócitos através da técnica de gradiente de centrifugação Ficoll-Paque®. Em seguida, as células foram estocadas em Trizol ${ }^{\circledR}$ (Invitrogen) ou Brazol ${ }^{\circledR}$ (LGC) em freezer a $-80^{\circ} \mathrm{C}$. Após o armazenamento, os DNA foram extraídos e quantificados através de leitura por espectrofotometria. Após a extração de DNA, foi realizado PCR para o gene da ß-globina. As amostras com resultado positivo nesse PCR foram submetidas à reação de PCR para os éxons 12 e 26 do gene MDR1. Os produtos de PCR para os éxons 12 e 26 foram digeridos com enzimas de restrição através da técnica de RFLP e corridos em gel de poliacrilamida a $8 \%$. O polimorfismo foi analisado de acordo com o padrão de bandas após a digestão com enzimas de restrição. Resultados: A análise dos resultados levou em consideração a faixa etária, sexo e cor dos pacientes. No éxon 12, não houve diferença entre a faixa etária até 35 anos (faixa 1) e a faixa a partir de 35 anos (faixa 2). Já no éxon 26, a faixa 1 apresentou 16\% de genótipo CC e $19 \%$ de TT contra $33 \%$ de CC e $5 \%$ de TT na faixa 2 . Não houve diferença quanto ao sexo, com exceção do genótipo CT do éxon 26 cuja freqüência observada foi de $75 \%$ no sexo feminino contra $56 \%$ do sexo masculino. Nos dois sexos, predominou o genótipo CT. Apesar de não haver número significativo de indivíduos estudados, com relação à cor, a população branca apresentou $43 \%$ de genótipo CC no éxon 12 contra $17 \%$ em mulatos. A freqüência de CT em mulatos (77\%) foi maior do que em brancos (52\%). Não houve diferença na frequiência dos genótipos do éxon 26, levando em consideração a cor. Discussão e conclusão: Os resultados desse trabalho demonstram maior frequiência do genótipo CT na população brasileira em relação a estudos já publicados e reforça a importância de estudos genotípicos em populações miscigenadas.
\end{abstract}

E-mail: hemato_hc@inca.gov.br 


\title{
Estudo fase II de gemcitabina e cisplatina neoadjuvante seguida de cirurgia em pacientes com câncer de bexiga localmente avançado: avaliação molecular para predição de resposta à quimioterapia através da relação mRNA $X I A P / X A F-1$
}

\author{
Séllos $\mathrm{J}^{1}$, Pinho $\mathrm{M}^{1}$, Costas $\mathrm{Fl}$, Small I', Xavier $\mathrm{M}^{1}$, Herchenhorn $\mathrm{D}^{2}$, Affonso $\mathrm{F}^{2}$, Campos $\mathrm{F}^{3}$, Quirino $\mathrm{R}^{3}$, Guimarães $\mathrm{D}^{1}$, Ferreira CG \\ I Serviço de Pesquisa Clínica, INCA \\ ${ }^{2}$ Serviço de Oncologia Clínica, INCA \\ 3 Serviço de Urologia, INCA
}

Introdução: Vários estudos (Roy et al., 1997) demonstraram a correlação in vitro entre a expressão das proteínas inibidoras de apoptose (IAP) e a quimiosensibilidade. Dentre as IAP, a XIAP demonstrou ser a mais importante e potente inibidora da caspase-9 (uma caspase essencial na apoptose induzida por quimioterapia). Recentemente, foi descrita uma molécula inibidora da XIAP, chamada XAF1 (Fong et al., 2000). Já foram descritas duas isoformas de XAF1 geradas por splicing alternativo, o que sugere que possa haver outras isoformas de XAF1. No entanto, o impacto da expressão de XAF1 nunca foi avaliado em amostras tumorais. Em etapas anteriores ao projeto, foi identificada uma possível nova isoforma cuja seqüência foi obtida a partir de três linhagens celulares com origens diferentes e teve sua expressão avaliada. Metodologia e Resultados: 1. Validação da reação de PCR para amplificação de todo o cDNA da nova isoforma com o objetivo de seqüenciar a mesma e compará-la com a isoforma nova publicada recentemente. 2. Amplificação de parte do cDNA da nova isoforma da metade até a região 3' não traduzida. 3. Amplificação da região 5' não traduzida até o novo éxon, utilizando o kit RACE (Rapid Amplification of $c D N A$ Ends) bem como purificação a partir de eletroforese em gel de agarose. 4. Avaliação da citotoxicidade de linhagens celulares à cisplatina e paclitaxel. 5. Reação de transcrição reversa (RT) a partir de RNA extraído de tumores de bexiga dos pacientes incluídos no estudo bem como padronização dos mesmos, objetivando a avaliação da expressão por PCR em tempo real (já realizada pelo aluno de doutorado Marcos Pinho). 6. Seqüenciamento da região 5' não traduzida da nova isoforma que está em andamento.

E-mail: cferreira@inca.gov.br 


\title{
Estudo da perda de heterozigose no gene $R B 1 \mathrm{em}$ pacientes com retinoblastoma
}

\author{
Aguiar FCC' ${ }^{\text {; Barbosa RH}}{ }^{1}$; Bonvicino $\mathrm{CR}^{1,2}$ \\ 1 Divisão de Genética, INCA \\ ${ }^{2}$ Departamento de Medicina Tropical, Instituto Oswaldo Cruz
}

O gene $R B 1$ possui $183 \mathrm{~kb}$ e está distribuído em 27 éxons localizados na região 13q14. A perda de função desse gene pode levar ao retinoblastoma, um tumor maligno das células retinianas que atinge crianças de até 7 anos de idade. Para a manifestação desta neoplasia, é necessário que ocorram dois eventos mutacionais complementares e independentes. Desses, a perda de heterozigose (Loss of heterozygosity - $L O H$ ) é o segundo evento mais comum, ocorrendo em $60 \%$ dos casos, de acordo com a literatura. A fim de se verificar se houve LOH no gene RB1, foram analisadas amostras de sangue periférico e de tumor incluído em parafina de 25 pacientes com retinoblastoma. Foi realizada a extração de ADN em todas as amostras e amplificação de três regióes microssatélites do gene RB1, através de um marcador polimórfico intragênico (D13S153) e dois flanqueadores (D13S262 e D13S284). Em seguida, os produtos amplificados foram verificados em gel de agarose 1,5\% e analisados em um seqüenciador automático $\left(\mathrm{MegaBace}^{\mathrm{TM}}\right)$. Foram analisadas, ainda, amostras de $\mathrm{ADN}$ extraído de sangue periférico dos genitores de dois pacientes para verificar a origem parental do alelo retido no tumor. Dos 25 pacientes, todos os três marcadores foram amplificados a partir das amostras de ADN de sangue periférico e em 16 amostras de tumor. A perda de heterozigose do gene RB1 foi observada em $60 \%$ dos pacientes, em concordância com os dados da literatura. Em $40 \%$ dos pacientes, não foi verificada a perda de heterozigose nos marcadores analisados; portanto o segundo evento mutacional nesses indivíduos pode ter sido mutação pontual, metilação da região promotora ou rearranjo cromossômico. Em um dos pacientes, foi observada a perda do alelo paterno e retenção do alelo materno no tumor, em relação ao marcador D13S153. Devido aos problemas encontrados para análise de material tumoral, foram necessárias duas modificações no protocolo utilizado. A primeira alteração foi para eliminar os resíduos contaminantes presentes em algumas amostras de ADN tumoral, através da purificação do ADN com o kit de purificação para produtos de PCR (Gel Band Purification kit - Amershan ${ }^{T M}$ ). A segunda visou a melhorar a digestão do tecido tumoral, com o acréscimo de uma etapa de hidratação. Através disto, houve uma melhora substancial na qualidade do ADN. Estas novas condiçōes possibilitarão melhores resultados de amplificação e genotipagem, a fim de verificar se houve perda de heterozigose nos pacientes ainda não analisados.

E-mail: cibelerb@inca.gov.br 


\title{
Regulação da atividade das células T pelo estroma de medula óssea
}

\author{
Lima RF'1, Monteiro JP1,3, Bonomo $\mathrm{A}^{1,2}$ \\ ${ }^{1}$ Divisão de Medicina Experimental / INCA \\ ${ }^{2}$ Departamento de imunologia Instituto de Microbiologia Prof. Paulo Góes/ UFRJ \\ ${ }^{3}$ Programa de formação de pesquisa médica/ FM/ UFRJ
}

A medula óssea é o principal sítio de hematopoiese em mamíferos adultos. Recentemente, demonstramos que a atividade das células $\mathrm{T} \mathrm{CD}^{+}$é essencial na manutenção da hematopoiese normal e que essa atividade requer (i) ativação pelo antígeno cognato e (ii) presença destas células na medula óssea. No entanto, esse constante estado de ativação das células $\mathrm{T} \mathrm{CD}^{+}$precisa ser controlado, a fim de não lesar o tecido hematopoiético. $\mathrm{O}$ estroma de medula óssea parece exercer um importante papel neste contexto, inibindo a atividade das células $\mathrm{T}$ por mecanismos ainda desconhecidos. Demonstramos previamente que o estroma de medula óssea é capaz de inibir a proliferação e apoptose de células leucêmicas, através de interação via junções comunicantes. O presente trabalho visa a analisar se o estroma de medula óssea estabelece junções comunicantes (JC) com as células T $\mathrm{CD}^{+}$e se esta interação é responsável pela inibição da atividade linfocitária. Com o objetivo de avaliar o estabelecimento de JC entre os dois tipos celulares, células de linfonodos de camundongos DO11.10 - cujas células T CD4 $4^{+}$têm TCR específico para pOVA + I- $A^{d}$ - foram estimuladas ou não com ovalbumina solúvel na presença de células da linhagem S17, representativas do estroma de medula óssea murino. As células estromais foram previamente marcadas com calceína-AM, um corante fluorescente citoplasmático que permite análise do acoplamento via JC por citometria de fluxo. Observamos que cerca de $90 \%$ das células T CD4 ${ }^{+}$estabeleceram JC com o estroma, independentemente de estimulação. $\mathrm{O}$ alto percentual de células calceína positiva é realmente decorrente de acoplamento, já que a marcação com calceína é negativa se as células forem cultivadas sem contato físico. Além disso, culturas de linfócitos que receberam o sobrenadante de co-culturas marcadas com calceína apresentaram marcação negativa para o corante. Esses controles indicam que não havia calceína livre no sobrenadante das co-culturas e que os linfócitos se tornavam calceína+ somente pelo contato direto com o estroma. Ao avaliarmos a atividade destes linfócitos que estabeleceram JC com o estroma de medula óssea, observamos que as células T CD4 ${ }^{+}$de BALB/c estimuladas com mitógenos ou antígenos na presença do estroma (i) têm a proliferação completamente inibida, num fenômeno dependente de contato celular e de dose (a mínima relação estroma/linfócito capaz de inibir completamente a proliferação é 1:2,5); (ii) não produzem IFN $\gamma$ (apenas $1 \%$ das células produtoras na presença contra 67\% na ausência do estroma); (iii) expressam marcador de ativação recente CD69. Os dados apresentados sugerem que há relação entre o fenômeno de acoplamento celular via JC e o fenômeno de inibição da atividade das células $\mathrm{T} \mathrm{CD}^{+}{ }^{+}$pelo estroma de medula óssea, uma vez que cerca de $90 \%$ dos linfócitos interagem via junções com o estroma e têm produção de IFN $\gamma$ e a proliferação fortemente inibida por ele num efeito dependente de dose e contato celular. Aparentemente, a sinalização da ativação das células T $\mathrm{CD}^{+}{ }^{+}$via TCR é interrompida na presença do estroma, já que os linfócitos são capazes de expressar a molécula CD69, mas não são capazes de proliferar e produzir citocinas. Nesse momento, buscamos confirmar a correlação entre os fenômenos de acoplamento e inibição, realizando ensaios com peptídeos inibidores de JC e avaliando em qual etapa a sinalização de ativação das células $\mathrm{T} \mathrm{CD}^{+}{ }^{+}$é interrompida.

Financiamento: FAF-INCA, CNPq, FAPERJ. E-mail:abonomo@inca.gov.br 


\section{Estudo piloto do DNA transrenal como potencial marcador tumoral em linfomas Foliculares}

Faget DV, Bonamino M, Barcinski MA, Gimba E

Laboratório: MEDEX/INCA

Os marcadores tumorais para o linfoma folicular, atualmente utilizados na clínica são insatisfatórios devido a dados limitados em termos de especificidade e sensibilidade. Moléculas de DNA circulante encontradas no plasma podem constituir novos importantes marcadores. O DNA circulante é originado de células que sofreram apoptose ou necrose e é capaz de atravessar a barreira transrenal com suas informações genéticas preservadas. Esse DNA é chamado de DNA transrenal (Tr-DNA). O linfoma folicular é o segundo tipo mais comum de linfomas nãoHodgkin e cerca de $80 \%$ dos pacientes possuem a translocação t $(14 ; 18)$, a qual é responsável pela superexpressão da proteína anti-apoptótica Bcl-2. A translocação pode ocorrer em dois pontos de quebra: o major breakpoint (MBR) e o minor cluster region (mcr), presentes no cromossomo 18. A proposta de ter a identificação da $\mathrm{t}(14 ; 18)$ através do Tr-DNA leva em consideração que este seria um método não invasivo de diagnóstico, evitando punções venosas e medulares. O presente estudo tem por objetivo a detecção da t(14;18), com o ponto de quebra MBR, no Tr-DNA de pacientes com linfoma folicular positivos para esta translocação. Serão utilizados neste estudo $12 \mathrm{ml}$ de urina de indivíduos controles sadios sem história prévia de neoplasias e de pacientes com linfomas foliculares portadores ou não da translocação $t(14 ; 18)$. As amostras de urina são neutralizadas com uma solução de TrisEDTA e após essa etapa, isotiocinato de guanidina é adicionado à urina numa concentração final de $4 \mathrm{M}$ juntamente com a Wizard Resin (Promega), seguindo as instruçôes do fabricante. Após eletroforese em gel de poliacrilamida e posterior coloração pela prata, verificou-se a presença de fragmentos de DNA com tamanhos variando entre 0,7$2,0 \mathrm{~Kb}$ e $0,2-0,4 \mathrm{~Kb}$. As amostras de Tr-DNA foram quantificadas em um espectrofotômetro (NanoDrop), com rendimentos variando entre 4 e $20 \mathrm{ng} / \mathrm{ml}$. Através da realização de ensaios de reação em cadeia da polimerase (PCR) com oligonucleotídeos específicos para b-globina e b-actina, testamos o potencial de amplificabilidade desse Tr-DNA extraído de doadores sadios. Os produtos de amplificação gerados por estas reaçóes geram fragmentos de DNA com tamanhos de $175 \mathrm{bp}$ e $452 \mathrm{bp}$, respectivamente. Estes resultados preliminares nos mostram que o método aplicado para extração do Tr-DNA mostra-se eficiente e que as moléculas de Tr-DNA são compatíveis com o tamanho dos fragmentos de DNA correspondentes à $t(14 ; 18)$ do tipo MBR, que variam entre $180 \mathrm{bp} e$ 300bp. Este projeto foi recentemente aprovado pelo Comitê de Ética em Pesquisa do INCA e as coletas de urina de pacientes com linfoma folicular estão sendo iniciadas neste momento.

Financiamento: CNPq, FAF, Swiss Bridge Foundation. E-mail: egimba@inca.gov.br 


\title{
Biogênese de autofagossomos em resposta à radiação em células de adenocarcinoma de cólon humano/HCT-116
}

\author{
Albuquerque-Xavier AC e Morgado-Díaz JA \\ Grupo de Biologia Estrutural, Divisão de Biologia Celular, Centro de Pesquisa/INCA
}

\begin{abstract}
Autofagia é uma via de degradação intracelular de macromoléculas e organelas, que pode ser induzida por privação de aminoácidos, tratamento hormonal e irradiação ionizante. Nos últimos anos, o estudo de autofagia tem apresentado duas faces antagônicas: a eliminação de tumor através de estímulo de morte celular não apoptótica ou uma resposta adaptativa de células tumorais. O presente estudo visa a estudar a biogênese de autofagossomos após radiação ionizante em células de adenocarcinoma de cólon humano/HCT-116, visando a identificar as vias de sinalização celular que estariam regulando este processo. A análise por citometria de fluxo não mostrou diferenças significativas nos níveis de apoptose em células irradiadas comparadas ao grupo controle, 48h após irradiação, indicando um mecanismo de proteção celular. A análise por microscopia eletrônica de transmissão, 48h após irradiação, mostrou a formação de organelas com material eletrondenso variado em seu interior, ocupando grande parte do citoplasma. A análise usando BSA-Au como um marcador de autofagossomo, e inibidores específicos de vias de sinalização indicaram que PI3K, Erk 1/2 e Src participam da biogênese dessas organelas. Estes resultados foram confirmados por imunoblotting onde foram quantificadas a expressão total e o nível de fosforilação destas proteínas, em diferentes tempos após tratamento com radiação. Nossos resultados indicam o envolvimento das proteínas PI3K, Src e ERK1/2 na biogênese dessas organelas após radiação e que esta resposta estaria relacionada à proteção de morte celular por apoptose. Desta forma, nossos resultados podem contribuir para uma melhor compreensão do desenvolvimento e função dessas organelas e poderiam ser úteis nas terapias de cânceres epiteliais.
\end{abstract}

Apoio: CNPq, INCa-MS, FAF, Faperj.

E-mail: jmorgado@inca.gov.br 


\section{Auto-anticorpos contra osteopontina como potenciais marcadores séricos em neoplasias}

Tilli TM e Gimba ERP

Divisão de Medicina Experimental, CPQ/INCA

Resumo: Proteínas superexpressas em tumores podem constituir antígenos capazes de produzir resposta imune humoral específica. No presente trabalho, avaliamos a presença de anticorpos anti-osteopontina (OPN) como potenciais marcadores séricos em diferentes neoplasias. Para detecção desses anticorpos, utilizamos ensaios imunológicos para detecção de anticorpos anti-OPN circulantes contra a OPN recombinante. Estes dados apresentam as primeiras evidências de que anticorpos anti-OPN estão presentes em níveis mais elevados em uma proporção das amostras de soros das neoplasias investigadas, quando comparadas com amostras de indivíduos controles sadios e tumor benigno de próstata e ovário. Dados da literatura mostram que anticorpos contra proteínas tumorais, denominados de auto-anticorpos, podem constituir importantes marcadores séricos em neoplasias. A osteopontina (OPN) é uma glicoproteína secretada para a matriz extracelular, com funções biológicas bem caracterizadas no desenvolvimento da resposta imune e inflamatória, calcificação e remodelamento de tecidos mineralizados, angiogênese e carcinogênese. Seu importante papel na tumorigênese encontrase bem caracterizado, especialmente no carcinoma da mama. A superexpressão da OPN é observada em diversas neoplasias, em especial no câncer de próstata, ovário e mama . No presente trabalho, amostras de soros destas neoplasias foram avaliadas quanto à presença de anticorpos anti-OPN e comparadas com os níveis de reatividade desses anticorpos em amostras de soros de homens e mulheres sadios, sem histórico prévio de câncer, e de tumores benignos da próstata (HPB) e de ovário. A estratégia experimental consiste na utilização da proteína recombinante osteopontina em ensaios imunológicos de imunoblot e ELISA para deteç̧ão de anticorpos circulantes contra essa proteína. Ensaios de imunoblot mostraram que um pool de soros de pacientes com câncer de próstata reconhecem especificamente a proteína OPN recombinante, enquanto soros controles sadios apresentaram reatividade negativa. Ensaios de ELISA indiretos com OPN recombinante foram realizados frente a uma bateria de soros de diferentes neoplasias. Para estabelecer o ponto de corte, calculamos a média das D.O, resultantes de ensaios com 20 soros de indivíduos controles normais, somada a dois desvios padrōes. Dentre 7 amostras de soros de pacientes com câncer de próstata, 2 (2/7) apresentaram D.O. maior do que o ponto de corte. Cinco amostras de soros de pacientes com HPB foram testadas e nenhuma apresentou positividade (0/5). De 17 amostras de soros de diferentes neoplasias ginecológicas testadas (2 amostras de carcinoma de ovário, 4 amostras de tumor benigno de ovário, 10 amostras de adenocarcinoma de útero e 1 amostra de tumor benigno de útero), apenas 1 amostra de adenocarcinoma de útero metastático para ovário apresentou reatividade (1/17), enquanto que das 5 amostras de soros analisadas de pacientes com câncer da mama, 2 apresentaram positividade (2/5). Até o presente momento, não há dados na literatura que mostrem a existência de resposta imune humoral contra OPN em pacientes com câncer. Nossos dados, então, seriam os primeiros a abordar esta resposta de auto-anticorpos contra a osteopontina nas diferentes neoplasias investigadas. Em doenças auto-imunes, em especial osteoartrite e artrite reumatóide, existem dados dessa resposta auto-imune contra a osteopontina. Estes achados da literatura reforçavam a possibilidade da existência de anticorpos anti-OPN em neoplasias, já que diversas proteínas próprias em doenças auto-imunes, assim como o câncer, são capazes de ativar células $\mathrm{T}$ e $\mathrm{B}$, induzindo perda da tolerância imunológica. Os dados gerados até o momento apresentam evidências de que anticorpos anti-OPN estão presentes em níveis mais elevados em uma proporção das amostras de soros destas neoplasias investigadas, quando comparadas com amostras de indivíduos controles sadios e tumores benignos de ovário e de próstata. Para determinar a potencial utilização desses anticorpos como marcadores séricos em neoplasias, está sendo determinado o percentual de reatividade para anticorpos anti-OPN testando-se um maior número de soros para cada uma destas neoplasias. 


\title{
Lesões precursoras do câncer de colo do útero: Resposta Histológica para a controvérsia entre os exames colposcópico e citopatológico
}

\author{
Parreira VG, Parreira VAG, de Almeida Neto OF, da Silva IF \\ Núcleo de Estudos e Pesquisas HCII/INCA
}

Introdução: A avaliação das pacientes com citologia anormal é uma das principais indicações da colposcopia. No entanto, podem existir controvérsias em relação aos resultados dos exames colposcópicos e citológicos, dificultando a tomada de decisão em relação ao tratamento. Objetivo: Avaliar o resultado histopatológico de peças de biópsia ou conização de pacientes com alterações citológicas, nas quais o exame colposcópico não evidencia lesão. Metodologia: Estudo observacional descritivo, que avaliou 250 mulheres, com indicação para colposcopia, atendidas no Hospital do Câncer II. Dessas, $111(44,4 \%)$ não apresentaram lesão à colposcopia, que indicasse biópsia ou CAF, sendo repetido o exame citológico. Deste grupo, 29 mulheres $(26,1 \%)$ apresentaram nova lesão à citologia, sendo realizada a retirada do canal endocervical. Este último grupo compõe a população do estudo. Foram coletadas informaçōes sociodemográficas, histórias clínica e ginecológica, resultados dos exames colposcópicos, citológicos e histopatológicos a partir dos prontuários das pacientes atendidas no projeto. Foi efetuada uma análise exploratória utilizando medidas de tendência central e proporções, aplicando o teste t- de S'tudent e o qui-quadrado, ambos com 95\% de intervalo de confiança. Resultados: O grupo de mulheres estudado se caracteriza por mulheres em sua maioria da cor parda (44\%), solteiras (48\%), usuárias de contraceptivos orais $(70,3 \%)$ e expostas ao tabagismo passivo (77,7\%). A prevalência de tabagismo atual foi de $18,5 \%$ e passivo foi de $37 \%$. O número de DST e o tempo de uso de pílulas anticoncepcionais apresentaram uma correlação estatisticamente significativa com a gravidade da lesão ( $\mathrm{p}=0,022$ e $\mathrm{p}=0,009$, respectivamente). As alteraçôes citopatológicas de neoplasias intraepiteliais cervicais de alto grau (HSIL) apresentaram maior correspondência à histologia (62,5\%), quando comparadas às de baixo grau e negativas $(37,5 \%$ e $50 \%$, respectivamente). O resultado colposcópico não esteve relacionado ao grau de lesão cervical. Mulheres com idade entre 25 e 35 anos apresentaram maior concordância (80\%) entre os exames citológicos e histopatológicos, quando comparadas às mulheres com menos de 25 anos e mais de 35 anos. Conclusão: Em mulheres com alterações citológicas, nas quais o exame colposcópico não evidencia lesão, as lesões de alto grau são as que apresentaram maior grau de correspondência histopatológica. $\mathrm{O}$ exame colposcópico parece não influenciar a concordância entre os exames. 


\title{
Análise da inibição de Ciclooxigenase-2, em combinação com o tratamento quimioterápico, em células tumorais de pulmão NSCLC
}

\author{
Duarte ML, Pontes E, Moraes JL, Ferreira CG e de Moraes E \\ Serviço de Pesquisa Clínica/INCA
}

Introdução: $\mathrm{O}$ câncer de pulmão é uma das principais causas de morte no mundo e a sua incidência continua a crescer de forma assustadora (Ferlay et al., 2004). Devido ao rápido aparecimento de resistência das células tumorais aos tratamentos convencionais de quimioterapia, é necessário desenvolverem-se novas formas de tratamento, a partir da identificação de moléculas-alvo. Estudos relatam a superexpressão da enzima inflamatória ciclooxigenase2 (Cox-2) em diversos tumores, e demonstram que o aumento na síntese de prostaglandinas é capaz de induzir a proliferação celular e inibir a apoptose (Cao e Prescott, 2002). Com isso, sugere-se que os inibidores seletivos de Cox-2 possam ser utilizados como co-adjuvantes na terapia do câncer, aumentando o efeito citotóxico de agentes quimioterápicos. O objetivo deste trabalho é avaliar o efeito da inibição de Cox-2 na proliferação celular, e investigar o co-tratamento de celecoxib juntamente com quimioterápicos (cisplatina e paclitaxel) em células não pequenas de câncer de pulmão (NSCLC). Metodologia: Quatro linhagens NSCLC (H460, A549, ACC-LC94 e ACC-LC319) foram selecionadas por apresentarem diferenças importantes quanto à expressão de Cox-2 e p53. Estas células foram tratadas com cisplatina ou paclitaxel apenas ou em combinação com o inibidor seletivo de Cox2, celecoxib. Através de ensaios de proliferação celular (ensaio MTT), foram determinados os IC50, e escolhidas as doses para os ensaios de combinação com celecoxib. A inibição da atividade de Cox-2 foi avaliada, através da dosagem de prostaglandina E2 (PGE2), por meio de um kit imunoensaio. Através do ensaio clonogênico, foi analisada a utilização de baixas doses de celecoxib e quimioterápicos como tratamento celular em longo prazo. A análise morfológica por marcação celular com o corante fluorescente Hoescht foi utilizada para a investigação de apoptose. Resultados e Conclusões: Os resultados demonstram que o tratamento com celecoxib só é capaz de inibir significativamente a viabilidade celular com doses de $100 \mathrm{mM}$. No entanto, os ensaios de dosagem de PGE2 mostram que a atividade de Cox-2 já encontra-se totalmente inibida com $10 \mathrm{mM}$ de celecoxib, mesmo após indução desta proteína após o tratamento quimioterápico com IC50 de cisplatina e paclitaxel. Visando a evitar efeitos independentes da ação de Cox-2, os ensaios de combinação foram realizados com 10mM de celecoxib. Surpreendentemente, não foi observada uma acentuada redução na proliferação celular em curto prazo (até $72 \mathrm{~h}$, ensaio MTT), em longo prazo (até 10 dias, ensaio clonogênico), ou aumento da apoptose (marcação Hoescht) após adição de celecoxib ao tratamento celular. Em conclusão, embora a superexpressão de Cox-2 seja apontada como um fator decisivo na progressão maligna, os resultados com tratamento de células tumorais de pulmão com celecoxib em combinação com quimioterápicos não foi mais eficaz do que o tratamento quimioterápico convencional. Mais estudos são necessários para se melhor conhecer as vias moleculares envolvidas.

E-mail:emoraes@inca.gov.br 


\title{
Indução de ciclooxigenase-2 após tratamento quimioterápico em células tumorais de pulmão NSCLC com diferentes status mutacionais de TP53
}

\author{
Schluckebier L, Pontes E, Moraes JL, Ferreira CG e de Moraes E \\ Serviço de Pesquisa Clínica/INCA
}

O câncer de pulmão apresenta alta taxa de incidência e mortalidade no mundo. Cerca de $80 \%$ dos casos são diagnosticados como o subtipo histológico NSCLC (células não pequenas). Devido ao rápido aparecimento de resistência das células tumorais à quimioterapia e à baixa expectativa de vida dos pacientes após cirurgia, torna-se imprescindível o melhor conhecimento das vias moleculares envolvidas na progressão do câncer de pulmão. Estudos relatam a superexpressão da enzima inflamatória ciclooxigenase-2 (Cox-2) em diversos tumores, favorecendo o desenvolvimento neoplásico. Há indicação na literatura de que o tratamento celular com quimioterápicos possa aumentar a expressão de Cox-2, induzindo resistência à morte celular. Sabe-se, também, que há alta freqüência de mutação no gene supressor de tumor TP53 em câncer, o que poderia alterar a resposta tumoral à quimioterapia. O objetivo deste trabalho foi analisar o efeito da quimioterapia na expressão de Cox- 2 em linhagens NSCLC com diferentes status de TP53. Foram utilizadas células contendo a proteína p53 selvagem (H460 e A549), mutante (ACC-LC-319) ou nula (ACC-LC-94 e Calu-1). As células foram tratadas com as drogas quimioterápicas cisplatina e paclitaxel (IC50) por diferentes intervalos de tempo. A expressão do RNAm de Cox-2 foi analisada através de RT-PCR semi-quantitativo e quantitativo em tempo real. A expressão das proteínas Cox-2, p53 e p21 foi investigada por Western Blotting. Os resultados mostram que ambos os tratamentos foram capazes de ativar rapidamente a proteína p53 e o seu gene-alvo p21 nas linhagens H460 e A549, o que não foi verificado nas linhagens mutantes. A expressão da proteína Cox-2 foi induzida após $24 \mathrm{~h}$ de tratamento, apenas em células contendo a p53 ativa. Nestas linhagens selvagens, a expressão do RNAm de Cox-2 foi induzida em aproximadamente dez e cinco vezes após tratamento das células com cisplatina e paclitaxel, respectivamente. Já nas linhagens com ausência da proteína p53 ativa, foi visto que há uma leve indução da expressão do gene Cox-2, embora não tão significativa quanto observada nas linhagens selvagens. Em conclusão, os resultados obtidos neste trabalho demonstram que o tratamento de quimioterápicos em células tumorais de pulmão é capaz de induzir a expressão do RNAm e da proteína de Cox2. Visto que esta indução só foi verificada em células contendo a p53 selvagem, os resultados sugerem que essa proteína possa ser importante na regulação da Cox-2 após danos ao DNA. Por fim, a quimioresistência, comumente observada no tratamento do câncer de pulmão, poderia ser explicada em parte, pela superexpressão indesejada de uma enzima com potencial anti-apoptótico e proliferativo.

E-mail:emoraes@inca.gov.br 


\title{
Expressão do CD26 em leucemias agudas
}

\author{
Ribeiro AJV'; Pombo-de-Oliveira MS'2 Pereira DA' \\ 'Divisão de Genética; ${ }^{2}$ Divisão de Medicina Experimental/INCA
}

O CD26 (dipeptidil-peptidase IV/DPPIV) é uma sialoglicoproteína transmembranar, que apresenta múltiplas propriedades funcionais. Possui atividade exopeptidásica, clivando dipeptídios na seqüência N-terminal de polipeptídeos e proteínas, quando a prolina ou a alanina é o penúltimo aminoácido da seqüência. É expresso em diversos tipos celulares, incluindo linfócitos T e B. No sistema imune, atua como uma molécula de ativação de células $\mathrm{T}$, onde regula quimiocinas e se associa fisicamente com moléculas de importância imunológica, como adenosina-deaminase (ADA) e CD45. Além disso, parece exercer um importante efeito na mobilização de célulastronco e células precursoras hematopoiéticas. Substratos naturais para o CD26 são peptídeos que contêm prolina, como algumas citocinas e fatores de crescimento, muitos deles envolvidos na hematopoiese. Investigaçōes recentes sugerem que o CD26 está envolvido no desenvolvimento de certos cânceres humanos, incluindo malignidades hematológicas. Neste estudo, nosso objetivo é verificar a expressão do CD26 em células de sangue periférico de pacientes com LLA-T, LLA-B e LMA e comparar com resultados obtidos a partir de indivíduos saudáveis. Foram incluídos no estudo dez pacientes de ambos os sexos, com idade entre 5 e 19 anos e sem tratamentos prévios. A presença de CD26 na membrana das células foi caracterizada por citometria de fluxo, no Instituto Nacional de Câncer. Foram considerados positivos os casos que apresentaram mais de $20 \%$ de células mononucleares reativas com anticorpo anti-CD26. Análises por RT-PCR foram feitas para caracterizar a presença do transcrito do CD26. Em quatro casos, a presença de CD26 na membrana foi concordante com a presença do transcrito de CD26. Da mesma forma, a ausência da proteína coincidiu com a ausência do RNAm em três casos. No entanto, foram detectados os transcritos de CD26, porém não houve expressão de CD26 na membrana em três casos, sugerindo que, apesar da ausência da proteína, houve expressão de CD26 ao nível transcricional. Resultados provenientes de indivíduos saudáveis estão sendo investigados, com o objetivo de comparar o padrão de expressão do CD26 entre as células leucêmicas e as células normais. A regulação homeostática da hematopoiese envolve a expressão controlada de citocinas e de seus receptores. Se encontrarmos uma diferença significativa entre o padrão de expressão do CD26 nas células leucêmicas e nas células normais, é provável que sua expressão em níveis alterados seja um fator relevante nas transformações malignas do sistema hematopoiético. 


\title{
Modulação da resistência às drogas mediada pelo sistema glutation em linhagens tumorais, exibindo diferentes fenótipos de resistência
}

\author{
Ferreira ACS; Maia R; Kwee JK \\ Laboratório de Hematologia Celular e Molecular, Serviço de Hematologia, HCI/INCA
}

\begin{abstract}
Introdução: As alteraçôes da atividade das enzimas da família da glutationa $S$ transferase (GST) e altas concentraçôes do seu substrato glutationa (GSH) têm sido correlacionadas com a resistência a múltiplas drogas (MDR) mediada pelas proteínas MRP (proteína relacionada à resistência a múltiplas drogas), Pgp (glicoproteína $\mathrm{P}$ ) e $\mathrm{BCRP}$ (breast cancer resistance protein) em diversos tipos de tumores malignos. Objetivo: $\mathrm{O}$ objetivo deste trabalho é estudar formas de modulação dos níveis de concentração de GSH e da atividade da GST em linhagens tumorais que apresentam diferentes fenótipos de resistência aos quimioterápicos, visando à obtenção de informações sobre o possível benefício do emprego de agentes reversores dos níveis de GST e GSH em células tumorais que exibem esse fenótipo de resistência associado à presença das proteínas MDR. Materiais e métodos: A atividade da enzima GST, assim como a concentração de GSH foram analisadas por espectrofotometria a 340 e $414 \mathrm{~nm}$, respectivamente. Empregou-se o ensaio MTT, para avaliação da viabilidade celular nas linhagens leucêmicas K562, K562-Lucena, GLC4, GLC4-ADR e MCF7 na presença ou ausência de imatinibe, trióxido de arsênico, butionina sulfoximina (inibidor da GSH) e ácido etacrínico (inibidor da GST). Resultados: As linhagens MDR positivas apresentaram níveis de GSH maiores do que as suas linhagens parentais. A linhagem MCF7 apresentou uma maior sensibilidade ao inibidor da GSH. Tanto a linhagem K562 quanto a K562-Lucena e a GLC4 tiveram sua sensibilidade ao trióxido de arsênico aumentada em pelo menos $30 \%$. Já em relação ao imatinibe, não houve alteração significativa na sensibilidade das linhagens K562 e K562-Lucena. Conclusões: Nossos resultados comprovam que a modulação da GSH aumenta a sensibilidade de linhagens que apresentam diferentes fenótipos de resistência frente a diferentes quimioterápicos. Isso nos faz crer que os conjugados de glutationa não são detoxificados exclusivamente pela MRP, podendo utilizar para tal alguma outra via de extrusão. Já em relação à sensibilidade ao imatinibe, existem evidências em nosso laboratório de que a principal enzima envolvida nesse processo é a catalase, o que justificaria nosso resultado negativo com a modulação da GSH nessas linhagens.
\end{abstract}

Financiamento: Swiss Bridge Foudation. E-mail: hemato_hc@inca.gov.br 


\title{
Regulação da biogênese de corpúsculos lipídicos em células epiteliais por mediadores inflamatórios
}

\author{
Piva B, Moreira LS, Bandeira-Melo C, Diaz BL \\ Divisão de Biologia Celular/INCA
}

Corpúsculos lipídicos são inclusões citoplasmáticas, ricas em lipídios e são encontrados em diversos tipos celulares. Os corpúsculos lipídicos são vistos como a principal estrutura intracelular responsável por estocar e disponibilizar ácidos graxos para a geração de eicosanóides. Esta participação é suportada pela localização de proteínas envolvidas na cascata metabólica do ácido araquidônico (AA) e co-localização do produto final desta via, a prostaglandina E2 $\left(\mathrm{PGE}_{2}\right)$. O processo inflamatório é essencial na resposta a injúrias teciduais, e envolve a participação de mediadores, como citocinas e eicosanóides. A $\mathrm{PGE}_{2}$ é o principal metabólito do AA produzido por células epiteliais, sendo um potente mediador capaz de modular a angiogênese, motilidade, sobrevivência e proliferação celular, que são processos importantes na restauração da homeostase do tecido epitelial após injúria. O nosso objetivo central é investigar a modulação da biogênese de corpúsculos lipídicos em células epiteliais por mediadores inflamatórios, analisando as vias de sinalização intracelular envolvidas. Utilizamos como modelo experimental uma linhagem celular derivada do epitélio intestinal normal de rato (IEC-6). A avaliação de corpúsculos lipídicos foi realizada através da marcação com tetróxido de ósmio e contagem por microscopia óptica de campo claro. Análise da expressão de proteínas foi realizada por SDS-PAGE e a produção de $\mathrm{PGE}_{2}$ por ELISA. Células confluentes que simulam a camada epitelial íntegra não apresentam corpúsculos lipídicos. Estímulos inflamatórios como IL-1 $\beta$, PAF e PMA não provocam alterações no número de corpúsculos lipidícos, enquanto a adição de AA induz a formação de corpúsculos lipídicos em IEC-6 confluente de maneira dose e tempo-dependente. O efeito do AA não parece ser dependente de $\mathrm{PGE}_{2}$, pois a adição deste metabólito não altera o número de corpúsculos lipídicos. A via de sinalização envolvida na indução de corpúsculos lipídicos por AA, analisada após o uso de inibidores seletivos, não depende de quinases como MEK 1 e 2, JNK, mas parcialmente de p38. Estudos recentes têm apresentado que a p38 tem um papel essencial na produção de citocinas e na indução de Cox-2, reforçando assim nossos achados que indicam a participação de corpúsculos lipídicos em processos inflamatórios envolvendo células epiteliais.

E-mail: bldiaz@inca.gov.br 


\title{
Silenciamento do gene $c$-MYC em uma linhagem de linfoma de Burkitt através de interferência de RNA
}

\author{
Pires $\mathrm{IB}^{1,3}$, Lassance $\mathrm{L}^{2,3}$, Seuanez $\mathrm{H}^{2,3}$ \\ ${ }^{1}$ Escola de Ciências Biológicas/UNIRIO \\ ${ }^{2}$ Departamento de Genética/UFRJ \\ ${ }^{3}$ Divisão de Genética/CPQ/INCA
}

O linfoma de Burkitt é um linfoma não-Hodgkin, de alto grau e apresenta elevada velocidade de crescimento correspondendo a aproximadamente $2 \%$ de todos os linfomas. A translocação, envolvendo o proto-oncogene $c$ $M Y C$, é uma característica genética constante no linfoma de Burkitt. As translocações podem ser dos tipos $\mathrm{t}(8 ; 14)$ (q24; $\mathrm{q} 32)$, ocorrendo em $80 \%$ dos casos e t(2;8)(p12;q24) e t(8;22) (q24;q11), ocorrendo nos 20\% restantes. As translocações resultam na justaposição do oncogene $c-M Y C$ a seqüências dos genes de imunoglobulinas e têm como conseqüência a desregulação da atividade do fator transcricional $c-M Y C$, o que leva as células tumorais a permanecerem em divisão e não se diferenciarem, gerando a uniformidade celular do tumor. Tendo em vista a característica oncogênica do gene $c-M Y C$, o objetivo do trabalho é bloquear, através da interferência de RNA, a expressão do gene $c-M Y C$ na linhagem celular Ramos derivada de paciente com linfoma de Burkitt cuja translocação é t $\mathrm{t} 8$;14)(q24;q32). Para isso, foi utilizado o plasmídio p-Silencer 2.0 U6 HYGRO que produz siRNA in vivo a partir de um molde de DNA. Como resultados, foi determinada a concentração do antibiótico higromicina a ser utilizada para a seleção das células transfectadas com o vetor, já que esse vetor confere resistência a esse antibiótico. Também, foi feita a padronização dos experimentos de transfecção utilizando para isso o vetor pEGFP o qual produz uma proteína que emite fluorescência, permitindo assim a análise da eficiência da transfecção através de citometria de fluxo. Uma vez determinada as melhores condiçõos de transfecção, foram feitos os experimentos de interferência de RNA transfectando por eletroporação a linhagem celular Ramos com o plasmídio pSilencer 2.0 U6 HYGRO contendo seqüências específicas para o silenciamento do gene $c-M Y C$ e o mesmo vetor contendo uma seqüência randômica para controle negativo do silenciamento. Foram coletadas amostras referentes a 3, 7, 10 e 14 dias após a transfecção e os respectivos RNA foram então extraídos. Foram feitas análises por PCR em tempo real para verificar se o gene foi silenciado com eficiência. Os resultados obtidos indicaram que não houve supressão da expressão de $c-M Y C$ nas células transfectadas quando comparados às células transfectadas com o controle negativo que produzia siRNA com seqüência randômica. Além disso, houve muita perda celular conseqüente da eletroporação e da posterior seleção em antibiótico. Este resultado negativo pode ser explicado pelo fato das três regiôes escolhidas para síntese dos siRNA não terem sido eficientes para suprimir a expressão deste gene. Para etapas futuras, serão utilizados novos siRNA sintéticos para experimentos de transfecção transiente e não os vetores de silenciamento utilizados até o momento.

E-mail: hseuanez@inca.gov.br 


\title{
Estudo proteômico da resistência a múltiplos fármacos na leucemia mielóide crônica
}

\author{
Corrêa S'; Pizzatti L'; Sá LA²; Souza KW'; Costa S3; Rumjanek V³; e Abdelhay E' \\ ' Divisão de Laboratórios do CEMO-INCA \\ ${ }^{2}$ Unidade Multidisciplinar de Genômica e Proteômica, IBCCF-UF \\ ${ }^{3}$ Laboratório de Imunologia Tumoral, IBQM-UFRJ
}

O fenômeno de múltipla resistência a fármacos (MDR) se caracteriza pela resistência cruzada a quimioterápicos não relacionados entre si em termos de estrutura molecular, modo de ação e célula alvo. A MDR está altamente correlacionada ao fracasso da quimioterapia de vários tipos de tumores, devido à sua origem multifatorial. Estão incluídos, dentre os fatores que podem originar o fenótipo MDR, alteraçôes no reparo do DNA, defeitos em genes controladores da apoptose, aumento na detoxicação intracelular de drogas e, sendo o mais expressivo em termos de desencadeamento da MDR, a ativação ou superexpressão de proteínas exportadoras de drogas. Essas proteínas pertencem à família de transportadores ABC (ATP Binding-Cassette), como a glicoproteína P (Pgp) - produto da expressão do gene MDR-1, a proteína relacionada à multiresistência $(\mathrm{MRP})$ e a proteína da resistência à mitoxantrona (BCRP/MXR). Elas funcionam como bombas de efluxo dependentes de energia, capazes de translocar para o exterior da célula uma variedade de drogas quimioterápicas, reduzindo sua concentração intracelular para níveis sub-letais. Apesar do conhecimento acumulado sobre proteínas exportadoras de drogas e sua relação com o fenótipo MDR, os mecanismos que levam ao fenótipo da MDR, a evolução do mesmo, as interações moleculares que contribuem, aparentemente, nas vias alteradas e proteínas envolvidas nesta resistência, ainda são pouco conhecidos. Portanto, é de grande importância a caracterização, a nível molecular, do padrão de proteínas relacionadas à resistência a múltiplos fármacos. Para tal, neste trabalho, utilizamos como modelo de estudo, linhagens celulares MDR e não-MDR, respectivamente Lucena e K562. A K562 é uma linhagem eritroleucêmica estabilizada de um paciente com LMC em crise blástica. Lucena é uma linhagem MDR que foi estabelecida a partir da linhagem K562, após exposição gradual dessas células a doses crescentes de vincristina, um quimioterápico. A tecnologia proteômica foi empregada a fim de compararmos o perfil proteômico das linhagens celulares K562 e Lucena-1. Um miligrama de cada extrato protéico foi precipitado em acetona $100 \%$ e utilizado nos géis 2-D. As proteínas foram separadas, na isoeletrofocalização, usando-se ImmobilineDrystrips (GE) de $11 \mathrm{~cm}$ e pH 4-7, por $78 \mathrm{kVh}$ no sistema Multiphor II (GE). Na segunda dimensão, géis SDS-PAGE de gradiente 8-18\% foram utilizados. Os géis foram escrutinados e analisados. Os spots foram identificados por espectrometria de massas pelo instrumento MALD-TOF-TOF (Applied Biosystems). Os perfis proteômicos das linhagens celulares K562 e Lucena foram estabelecidos, sendo resolvidas na janela de análise 100 proteínas no gel 2D de K562 e 85 proteínas no gel 2D de Lucena. Dentre as proteínas identificadas, 25 se encontravam superexpressas na linhagem Lucena e 40 proteínas se encontravam superexpressas em K562. Além disso, 120 proteínas presentes nas duas linhagens apresentam diferenças quantitativas de expressão. É sabido que, dentre as proteínas exportadoras, a glicoproteína P é a principal proteína envolvida no fenômeno MDR Lucena, devido sua gradual exposição à vincristina, possui o gene MDR-1 amplificado, expressando, portanto, a glicoproteína-P (Pgp) em sua membrana plasmática, sendo essa proteína funcional. Entretanto, essa proteína não pôde ser analisada por se encontrar fora da nossa janela de análise ( $\mathrm{pH}$ 4-7), por possuir ponto isoelétrico (pI) igual a 9,06 e por ser insolúvel ao tampão de reidratação utilizado na abordagem proteômica empregada. Entretanto, proteínas com função de detoxificação celular e extrusão de substâncias foram identificadas como superexpressas em Lucena, como a enzima Splice Isoform 3 of UDP-glucuronosyltransferase $2 B 28$ precursor. Ela tem um papel importante na conjugação e subseqüente eliminação de substâncias xenobióticas potencialmente tóxicas e de compostos endógenos. O papel desta, e de outras proteínas nas vias que promovem a resistência a múltiplos fármacos será objeto de estudo futuro. A partir dessas proteínas, maiores informações poderão ser anexadas para um melhoramento do tratamento do câncer, pela superação dos mecanismos de resistência. 


\title{
Análise da expressão gênica de GBP-2 e correlação com a mutação no gene TP53 no câncer de esôfago
}

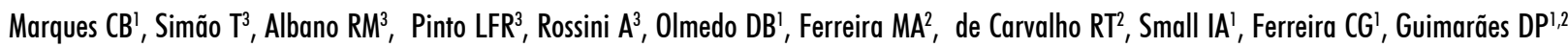 \\ ' Serviço de Pesquisa Clínica/INCA \\ ${ }^{2}$ Setor de Endoscopia Digestiva/INCA \\ ${ }^{3}$ Departamento de Bioquímica, Centro Biomédico/UERJ
}

Introdução: $\mathrm{O}$ câncer de esôfago é a sexta causa mundial de morte pela doença. Geralmente, diagnosticado em estágios avançados, apresenta um comportamento extremamente agressivo e um péssimo prognóstico. Nesse contexto, é fundamental a identificação de moléculas que participem da sua carcinogênese para a melhor compreensão do comportamento biológico desse tumor. A mutação no gene TP53 é uma das principais alterações genéticas encontradas durante o desenvolvimento desse câncer. Recentemente, o nosso grupo demonstrou a relação entre a ativação da proteína p53 e a indução do gene GBP-2 e da sua proteína (Guanylate Binding Protein-2) em uma linhagem de carcinoma epidermóide de esôfago (TE-1). Ainda, através da análise retrospectiva por imunoistoquímica, foi demonstrado que a expressão de GBP-2 foi significativamente maior no tecido tumoral do esôfago quando comparada com aquela do epitélio normal adjacente, sugerindo sua participação na carcinogênese esofagiana. Diante desse quadro, esse estudo teve como principais objetivos a análise da expressão gênica de $G B P-2$ no câncer de esôfago e a sua posterior correlação com a frequiência e o com padrão de mutaçôes no gene TP53. Pacientes e metodologia: Para investigar o papel de GBP-2 no desenvolvimento do câncer de esôfago, foram coletadas amostras de biópsias endoscópicas de tecido tumoral e de normal adjacente de pacientes com câncer de esôfago atendidos no Setor de Endoscopia Digestiva do INCA, entre Julho/2005 e Janeiro/2006. Dados demográficos e clínicos foram obtidos pela revisão dos prontuários médicos. Para o screening de mutações no gene TP53, usou-se a técnica de cromatografia líquida desnaturante de alta performance (DHPLC). Para validação do método e determinação da temperatura ideal de desnaturação parcial, o DNA da linhagem celular H460 (p53 selvagem) foi isolado e os éxons 5-9 do gene TP53 foram amplificados pela reação de PCR Touchdown. A análise de expressão gênica de GBP-2 foi feita pela reação de transcrição reversa seguida pela PCR em tempo-real (Q-PCR), usando sondas TaqMan ${ }^{\circledR}$. O RNA das amostras foi isolado usando-se o reagente TRIzol ${ }^{\circledR}$ seguido de tratamento pela DNAse. A normalização da quantificação de expressão de GBP-2 foi determinada pela amplificação concomitante do gene constitutivo GAPDH. A quantificação da expressão foi gerada pelo cálculo da diferença entre as médias de expressão de GBP-2 e de GAPDH. A aquisição dos dados for feita pelo programa 7000 System SOS Software (ABI Prisma 7000). Esse estudo foi aprovado pelo Comitê de Ética do INCA. Resultados: Até o momento, 20 pacientes foram incluídos no estudo. A idade mediana dos pacientes foi de 56,5 (22-74 anos). Dezessete (85\%), dentre 20 pacientes, eram do sexo masculino. Dezenove, dentre 20 pacientes $(94,7 \%)$, foram considerados como tabagistas, caracterizados pelo consumo de mais de 100 cigarros por toda a vida. Dezessete $(94,4 \%)$, dentre 18 pacientes, relataram o consumo de bebidas alcoólicas pelo menos uma vez por mês. $\mathrm{O}$ cromatograma de análise dos homoduplexes para os éxons 5-6 revelou dois picos ideais de temperatura, sendo elas $63^{\circ} \mathrm{C}$ e $65^{\circ} \mathrm{C}$. Para os éxons 8-9, as temperaturas ideais foram de $62^{\circ} \mathrm{C}$ e $63^{\circ} \mathrm{C}$. Para o éxon 7, não foi possível a determinação da temperatura ideal. A expressão gênica de GBP-2 por Q-PCR foi analisada em seis amostras pareadas, tecido normal adjacente e tumoral, relativas a três pacientes. $\mathrm{O}$ aumento de pelo menos duas vezes no tecido tumoral foi observado em dois, dentre os três pacientes, quando comparada ao tecido normal adjacente. Conclusões: Esse estudo permitiu a validação da metodologia de DHPLC para os éxons 5-6 e 8-9 do gene TP53. Análises adicionais serão necessárias para a determinar a melhor condição para o exon 7. Nossos resultados confirmam os resultados prévios de que a expressão 
de GBP-2 é maior no tecido tumoral do que no tecido normal adjacente. Entretanto, esse dado é referente a um número limitado de amostras e, assim, será necessária a sua confirmação em um número maior de casos.

Financiamento: Swiss Bridge Foudation, FAF, Ministério da Saúde. E-mail:dguimaraes@inca.gov.br 


\title{
Freqüência da fusão SIL-TAL1 em pacientes com leucemia linfoblástica aguda de linhagem $\mathrm{T}$
}

\author{
Mansur MB, Faria P, Menezes J, Emerenciano M, Sant'Ana M, Dantas J e de Oliveira MSP \\ Divisão de Medicina Experimental, Centro de Pesquisa - CPQ, INCA
}

A leucemia é um tipo especial de câncer que se origina em alguma célula presente na medula formadora das células sanguíneas ou na parte do sistema linfóide que existe na medula, sendo assim é uma doença caracterizada pelo acúmulo de precursores hematopoéticos. Alterações adquiridas em genes que regulam a hematopoese normal são freqüentemente detectadas nas leucemias, porém a progressão da doença depende de mutações adicionais que promovam a sobrevivência e o desenvolvimento do clone leucêmico. As leucemias linfóides agudas (LLA) são o mais prevalente tipo de câncer pediátrico. Dentro das LLA, 15\% correspondem às leucemias linfóides agudas de linhagem T (LLA-T). Baseado nos passos da maturação e no padrão de expressão dos antígenos de diferenciação, são identificados quatro estágios maturativos na linhagem T (T-I, T-II, T-III e T-IV), de acordo com a classificação EGIL. A fusão SIL-TAL1 é uma alteração genética exclusiva de LLA-T, presente em 16-26\% destas, apresentando maior incidência em crianças e adolescentes. Devido a esta alta freqüência, considera-se esta fusão como um bom marcador molecular de doença, além dos marcadores de antígenos celulares identificados pela imunofenotipagem. Uma outra característica da fusão é apresentar três tipos diferentes de transcritos (Tipo $A=111 \mathrm{pb}$, Tipo $\mathrm{B}=267 \mathrm{pb}$, e Tipo C=351pb) formados por splicings alternativos, estes combinam os éxons 1 a e $1 \mathrm{~b}$ do SIL com 3 e 4 do TAL1. Dentro deste contexto os objetivos deste trabalho foram determinar a freqüência da fusão SIL-TAL1 nos casos de LLA-T, e verificar a correlação existente entre as expressões de genótipo-fenótipo nos diferentes estágios maturativos das LLA de célula-T. Para tanto se usou citometria de fluxo com anticorpos monoclonais direcionados para os diferentes subtipos celulares, propiciando a determinação dos estágios maturativos, e RT-PCR com oligoprimers específicos para identificação da fusão gênica em estudo. Como resultados do estudo, observou-se que a freqüência do SIL-TAL1 em pacientes com LLA-T foi de 27,5\%, do total de 80 casos analisados, com uma relação diretamente proporcional de maior positividade em crianças com idade $<15$ anos. Em relação às etapas maturativas da célula T, a fusão foi mais freqüente nas etapas T-III e T-IV, respectivamente $8,75 \%$ e 7,5\%. Em revisão da literatura, não encontramos resultados consistentes que correlacionem as etapas maturativas com a presença da fusão SIL-TAL1. Nosso estudo é original neste sentido, pois há outros subtipos de LLA nos quais qual esta correlação genótipofenótipo já está bem estabelecida, como por exemplo, a expressão do CD10+ e sua associação com a presença da fusão TEL-AML1 ${ }^{3}$. Em relação aos tipos de transcritos formados como resultado da fusão, observamos que, dos 22 casos positivos, oito casos apresentaram somente o transcrito do tipo A, seis casos somente o do tipo B, um caso somente o do tipo $\mathrm{C}$, quatro casos exibiram os transcritos $\mathrm{A}$ e $\mathrm{B}$, um caso exibiu os transcritos $\mathrm{A}$ e $\mathrm{C}$, nenhum caso apresentou os transcritos $\mathrm{B}$ e $\mathrm{C}$ concomitantemente, e dois casos exibiram os três tipos de transcritos (A, B e C). Com estes resultados, faz-se necessária a continuação destes testes associados a outras possíveis alterações genéticas, para que se possa realmente avaliar a associação deste marcador como indicador de patogênese das LLA-T. Prospectivamente, testaremos a hipótese de que as mutações do gene NOTCH1 e as alterações nos genes $L M O 2$ e HOX11L2 associados ao rearranjo SIL-TAL1 estão ligadas à patogênese das LLA-T. 


\title{
Marcadores moleculares nos estudos epidemiológicos da LMA
}

\author{
Menezes J, Emerenciano M, Mansur M, Sant'Ana M e de Oliveira MSP \\ Divisão de Medicina Experimental/INCA
}

\begin{abstract}
A leucemia mielóide aguda (LMA) é caracterizada pelo crescimento descontrolado, pelo acúmulo de células chamadas mieloblastos e pela interrupção da produção normal de células da medula óssea. A análise cuidadosa das anormalidades nas células blásticas dos pacientes com LMA tem um profundo impacto na compreensão das mudanças moleculares envolvidas na leucemogênese. Algumas anormalidades genéticas são correspondentes a um subtipo de LMA que pode ser melhor classificado pela alteração genética do que pela morfologia, como é o caso da $\mathrm{t}(8 ; 21)$ e o subtipo M2, a t(15;17) e o subtipo M3 e a inv(16) e o subtipo M4Eo. Dentro deste contexto, o objetivo do nosso estudo foi detectar a presença de alterações cromossômicas, através de técnica de RT-PCR, nas LMA em uma coorte brasileira e correlacionar com as diferentes regióes do Brasil. Foram analisadas 87 amostras diagnosticadas como LMA pela análise morfológica e pela citometria de fluxo multiparamétrica. Dentre os resultados obtidos, observamos que $21,8 \%(\mathrm{n}=19)$ das amostras de LMA apresentavam a fusão gênica AML1/ETO e foi quase que exclusiva do subtipo FAB M2. A t $(15 ; 17)$ esteve presente em $17,2 \%(n=15)$ das amostras de LMA e somente nos subtipos M3/ M3v. No total das LMA estudadas, a fusão gênica CBFb/MYH11 correspondeu a 2,3\% $(n=2)$ e só esteve presente no subtipo FAB M4Eo, como o esperado na literatura. Observamos, também, que existe uma aparente prevalência da região nordeste sobre a sudeste no que diz respeito à presença da fusão gênica AML1/ETO. No entanto, mais estudos precisam ser feitos para se confirmar esta hipótese. Nosso número amostral ainda é bastante pequeno.
\end{abstract}

E-mail:mpombo@inca.gov.br 


\section{Mutação do gene GATAl em leucemias mielóides agudas em crianças com síndrome de Down}

Figueiredo $A B C$

MEDEX/NCA

As leucemias são doenças neoplásicas malignas oriundas de uma seqüência de eventos anormais que podem ocorrer durante a hematopoiese. Acredita-se que as leucemias agudas (LA) na infância são decorrentes de lesōes moleculares durante a vida intra-uterina ou durante a embriogênese, nas quais mutaçôes sucessivas desempenham um papel importante na codificação gênica podendo dessa forma predispor ao desequilíbrio celular resultando em alterações malignas. Entre as crianças que nascem com síndrome de Down (SD), um grupo com idade inferior a 3 anos tem alta probabilidade de desenvolver leucemia mielóide aguda (LMA) do tipo megacarioblástica ou LMAM7 pela classificação French-American-British (FAB). Embora a SD seja considerada uma condição de risco para leucemia, o elo de ligação entre a doença mieloproliferativa transitória (DMT) e LMA-M7, que são doenças hematopoiéticas comumentes ligadas à SD, é o gene GATA1, localizado no cromossomo X, que se encontra na via hematopoiética, sendo responsável pela diferenciação da via eritrocítica e magacariocítica. Este projeto tem como objetivo principal detectar mutações do gene GATA1 (éxons 2 e 3) em portadores de SD e doenças hematológicas com diferenciação megacariocítica e eritrocítica e estabelecer se realmente existem associaçôes específicas entre o gene GATA 1 e o status da proliferação clonal. Na realização deste projeto, foram utilizadas amostras de medula óssea (MO) e/ou sangue periférico (SP) de crianças com distúrbios hematopoiéticos obtidas no período de 1999 a 2004, seguidas de reação em cadeia da polimerase (PCR) e seqüênciamento. Foram analisadas 27 amostras de crianças com SD e doença hematológica clonal. Destas, apenas em uma foi encontrada mutação no éxon 2 (DMT) e em outra uma possível mutação no éxon 3, em um caso de eritroleucemia (LMA-M6) na qual se abre margem para uma nova investigação. Os resulados obtidos no sequenciamento do éxon 3, os quais não apresentaram mutação no éxon 2, mostram que em alguns casos pode haver outros fatores contribuindo com a leucemogênese.

E-mail:mpombo@inca.gov.br 


\title{
Envolvimento das proteínas Src e ERK1/2 na perda de adesão célula-célula mediada por TPA e EGF
}

\author{
De Souza WF e Morgado-Díaz JA \\ Biologia Celular/INCA
}

Um dos primeiros eventos para ocorrência de metástase de células tumorais é a desorganização dos contatos célulacélula. A E-caderina é uma glicoproteína que atua na organização de contatos célula-célula, regulando adesão, proliferação e motilidade celular. Foi relatado que a ativação do EGFR pode causar alterações morfológicas em células epiteliais, através da ativação da via de sinalização MAPK, levando à malignização das mesmas. Em um estudo prévio realizado pelo nosso grupo, foi proposto que a MAPK estaria modulando o processo de perda de adesão célula-célula, quando estimulada pelo tratamento com o éster de forbol TPA. Porém, pouco se sabe sobre as moléculas intermediárias que estariam atuando nesta transdução de sinal. Assim, o objetivo deste trabalho foi verificar o envolvimento das proteínas Src e ERK1/2 na perda de adesão célula-célula, mediada pela E-caderina em células Caco-2. Métodos e Resultados: Monocamadas de células Caco-2 foram tratadas com TPA ou EGF (fator de crescimento epidermal). Foi verificado, através de imunofluorescência, que estes agentes causaram redistribuição da E-caderina, dos contatos intercelulares para o citoplasma das células. Este efeito foi revertido pelo inibidor da proteína Src, PP1. Realizou-se a extração celular com Triton X-100, onde a fração solúvel neste correspondia às proteínas citoplasmáticas e a insolúvel às proteínas ligadas ao citoesqueleto. Através de imunoblotting, mostrou-se que o tratamento com TPA causou um aumento da expressão da proteína Src na fração associada ao citoesqueleto, sugerindo um aumento na sua ativação. Este efeito foi revertido pelo tratamento com o PP1. Além disso, verificouse também um aumento da ativação de ERK1/2 (MAPK), quando as células eram tratadas, tanto com TPA quanto com EGF. Pelo ensaio de migração, foi verificado que sob o efeito do TPA e EGF, as células apresentaram uma rápida mobilidade; esse efeito foi também prevenido pelo tratamento com PP1. Conclusão: Estes resultados mostram que as proteínas Src e ERK1/2 estariam participando da regulação da adesão célula-célula mediada pela E-caderina em células Caco-2 tratadas, tanto com TPA quanto com EGF.

E-mail: jmorgado@inca.gov.br 


\title{
Avaliação da informatividade de marcadores STR não- comerciais para a sua utilização em estudos de monitoramento do status do quimerismo. A sua utilização no estudo da leucemia mieloide crônica (LMC)
}

\author{
Borges AP, Braggio E, Hassan R, Lobo AM, Zalcberg I
}

Biologia Molecular - CEMO/INCA

A amplificação por PCR de regiōes STR (short tandem repeats) é a estratégia mais utilizada na avaliação do status do quimerismo pós-transplante alogênico de medula óssea. No entanto, a maioria destas regiốes foi otimizada para o uso em estudos forenses e não necessariamente apresentam as características desejáveis em marcadores utilizados para o estudo do quimerismo, considerando que na grande maioria dos casos analisados tem que se distinguir irmãos ou indivíduos geneticamente aparentados. Foi avaliada a informatividade de seis marcadores STR fluorescentes de repetições tetranucleotídicas em um grupo de 100 pares de pacientes e os seus respectivos doadores relacionados de medula óssea. O grau de informatividade variou amplamente entre marcadores, apresentando valores dentre 11 e 58\%. A heterozigozidade variou entre 62 e $88 \%$ nos diferentes marcadores e apresentou uma associação marginal com o grau de informatividade observada. Além da heterozigozidade, um maior número de alelos e, sobretudo, uma distribuição alélica balanceada foram características correlacionadas com o aumento da informatividade dos marcadores. Nossos dados demonstraram a importância na caracterização inicial de marcadores no intuito de identificar um grupo de regiôes STR ideais para estudos de quimerismo.

Uma avaliação precoce da pega e o subseqüente monitoramento do status do quimerismo poderiam ser utilizados na antecipação e manejo da rejeição do enxerto, doença enxerto contra hospedeiro (DECH) e recaída hematológica, antecipando assim intervençōes terapêuticas. Assim, o próximo passo foi analisar o potencial valor prognóstico do status do quimerismo na pega hematológica e a sua cinética posterior em pacientes com LMC. Foram estudados 49 pacientes que receberam transplante alogênico de medula óssea aparentado. A presença de quimerismo misto na pega não esteve associada com um risco maior de recaída hematológica $(P=0,44)$, ou com uma maior freqüência de desenvolvimento de DECH aguda $(P=0,73)$ ou crônica $(P=0,22)$. No entanto, uma cinética crescente do status do quimerismo (aumento relativo da proporção de células do receptor em relação às do doador, considerando pelo menos dois pontos do acompanhamento) antecipou a recaída hematológica em uma mediana de 125 dias (intervalo de 20 - 330 dias). Estes dados demonstram que o estudo do quimerismo na pega é uma ferramenta importante no monitoramento do enxerto e não na antecipação da recaída hematológica. Por outro lado, uma cinética crescente do quimerismo pode ser considerada um fator preditor da recaída em qualquer momento do acompanhamento pós-transplante.

E-mail:zalcberg@inca.gov.br 


\title{
Heterogeneidade molecular do vírus Epstein-Barr (EBV) em processos não-malignos e neoplasias linfóides EBV-positivos
}

\author{
Guiretti DM, Macedo MO, Barros MHM, Renault IZ, Hassan R \\ Biologia Molecular - Centro de Transplante de Medula Óssea - CEMO/INCA
}

\begin{abstract}
A associação entre o EBV e o câncer mostra variabilidade geográfica, decorrente da interação entre fatores genéticos do hospedeiro, características epidemiológicas das populações em risco e fatores do vírus. Neste trabalho, foram investigadas a prevalência e variantes moleculares do EBV, tanto em neoplasias linfóides como em tecido não tumoral, com o objetivo de contribuir para a caracterização da associação vírus/câncer na região Sudeste do Brasil. O EBV foi detectado por PCR para os genes EBER1 e BamW e por hibridização in situ (ISH) com sondas para o RNA $E B E R$. As PCR específicas foram desenhadas para amplificação diferencial de sequiências nos genes $E B N A 2$ e $E B N A 3 C$ (tipos 1 e 2) e das deleções de 30/69pb (del30/69) na região C-terminal do gene LMP1. Foram analisadas 248 neoplasias linfoma de Burkitt $(\mathrm{LB}) \mathrm{n}=67$; linfoma de Hodgkin (LH) $\mathrm{n}=71$; linfoma $\mathrm{T}$ periférico (LTP) $\mathrm{n}=30$; linfoma linfoblástico $\mathrm{T}$ (LBL-T), $\mathrm{n}=9$; linfoma anaplásico (LA) $\mathrm{n}=12$; linfoma difuso de grandes células B (LDCG-B) n=58; linfoma pós-transplante $n=1$ e 52 hiperplasias reativas (3 HIV+). A clonalidade foi determinada por PCR para rearranjos de imunoglobulina e TCRg. Em conjunto, 113 casos foram associados ao EBV: oito processos reativos (15\%) e 104 neoplasias; 61\% LB infantil, 67\% LB adulto; $73 \%$ LH infantil, 47\% LH adulto; 28\% LDGC-B; 33\% LTP; 11\% LBL-T; 0\% dos LA e um caso de linfoma pós-transplante. Ambos os subtipos virais, 1 e 2 , foram detectados ( $82 \%$ dos casos com tipo 1, 16\% tipo 2 e $2 \%$ ambos). Em relação aos processos não malignos ( $86 \%$ tipo 1 e $14 \%$ tipo 2), o tipo 2 mostrou tendência a estar associado aos LNH-B, enquanto que o tipo 1 foi mais freqüente nos linfomas T. O gene $E B N A 3 C$ foi importante na tipificação dos LB infantis, em que o EBNA2 não foi informativo em dois casos. A análise do gene LMP1 mostrou que $60 \%$ das neoplasias apresentavam a del30 ( $\mathrm{p}=0,056)$, enquanto $25 \%$ dos casos foram reativos. A del30 foi mais freqüente no LB e LH de adultos (64\%) em comparação com $25 \%$ nos LH infantis e 50\% nos linfomas T e LDGC-B. A del69 foi detectada somente em $2 / 38$ crianças com LB. A del30 foi relativamente mais freqüente no tipo viral $2(14 / 18)$ do que no tipo $1(50 / 94)(\mathrm{p}=0,06)$. Em resumo, este trabalho: (i) permitiu aprimorar uma abordagem integrada para o estudo da associação do EBV com diferentes cânceres, (ii) representa um estudo de um número expressivo de casos diagnosticados em um único centro, incluindo marcadores moleculares cujo papel patogênico é controverso, (iii) permite postular hipóteses sobre a natureza patogênica da associação entre o vírus, suas variantes e cada uma das patologias estudadas.
\end{abstract}

E-mail: biomol@inca.gov.br 


\title{
Análise do gene $L M P 1$ do vírus Epstein-Barr (EBV) em células não-tumorais e no linfoma de Hodgkin: seleção a favor da deleção de $30 \mathrm{pb}$ e da retenção de um motivo JAK3 na região C-ter e descrição de um novo padrão de mutações no promotor
}

\author{
Guiretti D, Macedo MO, Renault IZ, Hassan R \\ Biologia Molecular, CEMO/INCA
}

$\mathrm{O}$ vírus EBV encontra-se envolvido na patogênese do linfoma de Hodgkin (LH), expressando EBER, EBNA1 e a proteína latente de membrana 1 (LMP1), num programa denominado "latência II". A LMP1 é a principal oncoproteína do vírus, existem hipóteses que polimorfismos gênicos possam contribuir para o potencial transformador do vírus. O objetivo deste trabalho foi estudar a variabilidade molecular do gene LMP1 em 36 casos de LH (28 adultos, LHa e oito crianças, LHc), oito hiperplasias reativas (HR) e dois doadores saudáveis. O EBV foi detectado por PCR e hibridização in situ (EBER-ISH). A expressão da LMP1 foi detectada nas células R$S$ por imunoistoquímica e por RT-PCR (promotores EDL1-TR). A tipificação foi realizada por PCR para os genes EBNA2 e EBNA3C. A deleção de 30pb (del30), na região C-ter do gene LMP1, foi detectada por nested-PCR. A perda de um sítio de restrição XhoI, na posição 169428-433 (éxon 1), foi determinada por RFLP-PCR. Foi amplificado um fragmento do promotor (nt $-267 \mathrm{a}+1)$, da região N-ter (aa 1-40) e da região C-ter (aa 225-370), seguido por sequenciamento direto. A del(30) foi encontrada em $2 / 8 \mathrm{LHc}$ comparados com 18/28 LHa ( $\mathrm{p}=0,056$ ), e em 2/10 tecidos não-tumorais ( $\mathrm{p}<0,05)$, sugerindo seleção a favor da del(30) nos LHa. O sítio XhoI foi perdido em 5/10 (50\%) não-tumorais e em 8/20 (40\%) LHa analisados, 6/20 dos casos apresentando um padrão digerido/ não-digerido, indicando co-infecção ou variação intratípica. A análise da região C-ter $(n=31)$ mostrou que a maioria dos casos podia ser classificado nos tipos europeus A-C. Nos não-malignos, observou-se maioria de casos B (75\%), enquanto nos LHc 60\% foram B e 40\% B95 8/A. Nos Lha, 50\% foi do tipo C, coincidindo com a alta freqüência da del(30) neste grupo; $25 \%$ foi B e $25 \%$ A. Diferente da literatura, em que uma inserção de $15 \mathrm{pb}$ (aa 276-280) encontra-se associada somente aos tipos B95 8/A, em nossos casos a ins15pb foi observada em 8/9 LHa tipo $\mathrm{C}$ vs, 1 caso B LHc e 1 caso $\mathrm{B}$ não tumoral. Essa ins corresponde ao segundo motivo JAK3, no domínio CTAR-3. O fato da LMP1 em latência II ser regulada por STAT, assim como a presença concomitante da del30 sugere uma forte seleção positiva no LHa. Um novo padrão de mutações no promotor foi descrito nos LH e reativos desta região, que inclui mutaçôes recorrentes, algumas similares aos tipos D/CAO e outras típicas dos casos estudados. Todos os casos com este padrão (4/9) apresentaram (i) mutações no motivo ATF/CREB (-86 a 79), ativador da expressão EBNA2-independente; (ii) substituições nos aa 2, 3 e 24 (E $>\mathrm{D}, \mathrm{H}>\mathrm{L}$ e $\mathrm{L}>\mathrm{I}$ ) da região Nter; (iii) retenção do sítio XhoI e (iv) não estiveram associados a um padrão tipo D/CAO na região C-ter. Nos casos em que não apresentaram este padrão, foi verificada a presença da mutação $C>T$ na posição -200 e uma regiāo $\mathrm{N}$-ter convencional. Futuros estudos elucidarão a prevalência e diferenças na atividade biológica das variantes descritas. 


\title{
Estudo da regulação do gene galanina em células-tronco embrionárias
}

\author{
Maia $\mathrm{A}^{1}$, Gonzalez $\mathrm{SI}^{2}$, Amorim L', Fonseca $\mathrm{LG}^{1}$, Abelhay $\mathrm{E}^{2}$ \\ ${ }^{1}$ Departamento de Genética - Instituto Fernandes Figueira - FIOCRUZ \\ ${ }^{2}$ Laboratório de Células Tronco - Divisão de Laboratórios do CEMO/INCA
}

\begin{abstract}
A galanina é um neuropeptpídeo expresso no sistema nervoso central e periférico e tem como principais funçōes a regulação de hormônios hipofisários, a inibição da secreção de insulina, a indução da ingestão de lipídeos, a analgesia na medula espinhal e a regeneração de neurônios. Foi sugerido o seu envolvimento em diversas patologias, entre elas, vários tipos de câncer. Em adenomas induzidos por estrogênio, por exemplo, tem sido observado um aumento da expressão desse peptídeo, enquanto que em adenomas de tirotrófos a síntese de galanina é reprimida, sugerindo que ela possa atuar como um agente mitogênico célula-específico. Recentemente, foi sugerido que a galanina e seus receptores (Gal-R1, Gal-R2 e Gal-R3) possam estar envolvidos na fisiologia de células-tronco embrionárias de camundongo (ES), podendo estar relacionados com a via de sinalização de LIF e STAT, fatores importantes para a renovação dessas células. Para entendermos o papel da galanina na fisiologia das células ES, torna-se fundamental entendermos os mecanismos que regulam a sua expressão. Dessa forma, o objetivo desse trabalho é estudar os elementos responsáveis pela regulação da expressão do gene da galanina em células ES de camundongo. Para identificar estes elementos, nos baseamos no princípio de que seqüências que tenham sido conservadas entre espécies possam indicar uma conservação de função. Inicialmente, comparamos aproximadamente $1 \mathrm{~Kb}$ da região promotora do gene galanina de diversas espécies através do programa de alinhamento de seqüências (ALIGN). Estas seqüências foram posteriormente analisadas para identificar a presença de elementos reconhecidos por fatores de transcrição, através da utilização do banco de dados TRANSFAC® 7.0. A partir dessas análises, foram amplificados, através da técnica de reação em cadeia pela polimerase (PCR), quatro fragmentos da região promotora do gene galanina de camundongo, denominados EMSA1 (-813/-583), EMSA2 (-503/-286), EMSA3 $(-216 /-62)$, EMSA4 $(-86 /+35)$. Com o intuito de identificar fatores de transcrição presentes em células ES de camundongos que possam estar regulando a expressão de galanina nessas células, foram preparados extratos de proteínas nucleares que, em conjunto com os fragmentos de PCR, estão sendo utilizados em ensaios de alteração da mobilidade em eletroforese (EMSA). Resultados preliminares sugerem a interação de diversas proteínas nucleares aos fragmentos EMSA1 e EMSA3. Análises mais refinadas serão utilizadas para investigar essas interações.
\end{abstract}

E-mail: eabdelhay@inca.gov.br 


\title{
Estabelecimento, caracterização e potencialidade de células-tronco mesenquimais humanas a partir da medula óssea
}

\author{
e Costa JAC, Silva CL, Abdelhay E \\ Laboratório de Célula Tronco - Divisão de Laboratórios do CEMO,INCA
}

\begin{abstract}
Resumo: Dentro da medula óssea, existe uma fração de células de origem não-hematopoética conhecidas como células-tronco ou progenitoras mesenquimais (CTM). As CTM podem ser expandidas ex vivo e induzidas a se diferenciarem em progenitores de diversos tecidos, como osteoblastos, condrócitos, tenócitos, adipócitos, miócitos, fibroblastos do estroma medular e até em células da linhagem neural. A multipotencialidade, a facilidade de isolamento e cultivo, assim como o grande potencial de expansão em cultura tornam essas células uma atrativa ferramenta terapêutica para desordens da medula óssea e de tecidos mesenquimais. Diversos trabalhos têm mostrado o enorme potencial da CTM para a terapia coadjuvante ao transplante de medula óssea, induzindo a melhora na pega do transplante em modelos animais e em pacientes portadores de doenças hematológicas. Com o intuito de desenvolver tecnologias e terapias associadas ao transplante de medula óssea, neste projeto, estão sendo estabelecidas linhagens de CTM a partir de amostras de medula óssea de doadores do Centro de Transplante de Medula Óssea do INCA. As linhagens são estabelecidas a partir da fração de células mononucleares da medula óssea e estão sendo caracterizadas in vitro por análises morfológicas ao microscópio ótico e por ensaios de diferenciação para vários tipos celulares diferentes. Está sendo determinado também o perfil de unidades formadoras de colônia de fibroblastos em função do número de passagens das culturas, ensaio utilizado para quantificar o número de célulastronco mesenquimais de grande potencial proliferativo em uma determinada preparação celular. Até o momento, foram processadas cinco amostras de medula óssea, das quais foram estabelecidas linhagens de quatro. Os ensaios realizados com tais linhagens mostram o grande potencial proliferativo e de diferenciação das linhagens de célulastronco mesenquimais, o que estimula sua utilização como ferramenta terapêutica coadjuvante ao transplante de medula óssea.
\end{abstract}

E-mail: eabdelhay@inca.gov.br 


\title{
Análise proteômica das células-tronco hematopoiéticas de sangue de cordão umbilical
}

\author{
Villela AP'; Pizzatti L'; Sá LA²; Gomes BE'; Paraguassú-Braga FH'; Abdelhay E' \\ ' Divisão de Laboratórios do CEMO/INCA \\ ${ }^{2}$ Unidade Multidisciplinar de Genomica e Proteomica, IBCCF-UFRJ
}

A célula-tronco hematopoiética $(\mathrm{CTH})$ da medula óssea é definida como uma célula com grande capacidade de auto-renovação e potencial proliferativo, o que possibilita a sua diferenciação em células progenitoras de todas as linhagens sangüíneas e a reconstituição da população hematopoiética a partir de uma única célula. $\mathrm{O}$ transplante dessas células é a terapia de escolha no tratamento de doenças hematológicas, hemoglobinopatias e imunodeficiências. Neste tipo de procedimento, o próprio paciente pode ser utilizado como doador (transplante autólogo) ou, ainda, doadores relacionados ou não ao receptor podem ser fonte de célula-tronco (transplante alogênico). Recentemente, células do sangue de cordão umbilical e placentário (SCUP) têm sido apresentadas como fonte alternativa de progenitores hematopoiéticos, devido às inúmeras vantagens de seu uso como oferta ilimitada, possibilidade de armazenamento e maior facilidade de compatibilidade devido à baixa imunogenicidade. Neste trabalho, nós estudamos a variabilidade do perfil prôteomico de células CD34 ${ }^{+}$de unidades de SCUP com o objetivo de identificar as proteínas que definem este perfil e quais podem variar. De posse destes dados, poderemos compará-los com os obtidos de outras fontes de $\mathrm{CHT}$ a fim de definir que características moleculares são importantes para uma melhor pega. Neste sentido, definimos inicialmente o número mínimo de células mononucleares presentes numa unidade de SCUP para a separação de células CD34 . Experimentos preliminares demonstraram que a melhor recuperação é obtida em unidades coletadas a menos de 24 horas e que a celularidade ideal para o início da purificação é de 109 células mononucleares por SCUP. A separação das células CD34+ dos cordôes foi feita com o KIT Progenitor Cell Selection $\mathrm{CD}_{3} 4^{+}$(Dynal- Invitrogen), de acordo com o protocolo do fabricante. Após a separação e quantificação por citometria de fluxo, as proteínas foram extraídas e analisadas em géis bidimensionais. As proteínas primeiramente foram separadas, na isoeletrofocalização, usando-se tiras ImmobilineDrystrips (GE) de $11 \mathrm{~cm}$ de $\mathrm{pH} 4-7$ por $78 \mathrm{kVh}$ no sistema Multiphor II (GE). Na segunda dimensão, géis SDS-PAGE de gradiente 8-18\% foram utilizados, separando, assim, as proteínas por peso molecular. Os géis foram analisados e todos os spots foram retirados, processados e identificados por espectrometria de massas, utilizando-se o MALDI-TOF-TOF (Applied Biosystems). Foram, então, analisados os perfis proteômicos de células CD34+ obtidas de duas unidades de SCUP. Em cada perfil, foi possível identificar por MS/MS 120 proteínas, sendo 84 comuns aos dois perfis. Trinta e seis proteínas mostraram expressão diferencial entre as duas amostras, sendo que nove entre elas ainda não têm função definida. Estes resultados mostram que, apesar da variabilidade que existe entre as pessoas, foi possível identificar, numa janela de PI - 4 a 7 e PM - 6,0kDa a 180,0kDa, 84 proteínas que definem o perfil protéico de células CD34+ desta fonte. Análises de um maior número de unidades de SCUP permitirão aumentar a confiabilidade deste achado e provavelmente o número de proteínas identificadas. Interessantemente, algumas proteínas, diferencialmente expressas entre os dois SCUP analisados, indicam funçôes que poderiam estar relacionadas com a baixa imunogeinidade descrita para SCUP. Maiores estudos serão necessários para avaliação da correlação entre a presença dessas proteínas e a pega do enxerto. 


\section{Envolvimento da via PI3-quinase na diferenciação celular e formação do complexo juncional em células de adenocarcinoma de cólon, HTC-116}

Araújo WM e Morgado-Diáz JA

Grupo de Biologia Estrutural, Divisão de Biologia Celular/INCA

Fosfatidilinositol 3 quinase (PI3K) é um importante mediador da transdução de sinal intracelular e tem efeitos diretos na diferenciação, proliferação e sobrevivência celular. Sua ativação resulta na geração de um segundo mensageiro, o fosfatidilinositol $(3,4,5)$ trifosfato (PIP3). Na diferenciação de células intestinais que se caracterizam pelo desenvolvimento da polaridade celular com formação do complexo juncional, a participação do PI3K é ainda desconhecida neste processo. Durante a progressão tumoral do câncer colo-retal, a perda da polaridade celular e o aumento da proliferação são eventos característicos de alterações tumorais neste tipo de câncer. $\mathrm{O}$ objetivo do presente estudo foi verificar a participação da via PI3K, no processo de diferenciação enterocítico e seu envolvimento na formação do complexo juncional. Para investigar esse processo, células de adenocarcinoma cólon humano HCT-116, as quais apresentam um fenótipo indiferenciado, foram expostas a um inibidor de PI3K, o LY294002, por dez dias, a fim de induzir diferenciação celular. As células HCT-116, após o tratamento, apresentam-se em monocamadas e em desenvolvimento da polarização celular como verificado pela formação do complexo juncional ao nível de microscopia eletrônica. A análise por imunoblotting mostrou que células HCT-116 induzidas à diferenciação com o LY294002 expressaram proteínas das junçôes tight (claudina e ocludina) e das aderentes (E-caderina e ßcatenina). Além disso, a funcionalidade do complexo juncional formado foi verificada por microscopia eletrônica de transmissão, através da técnica do vermelho de rutênio. Estes resultados mostraram que a inibição de PI3K estaria induzindo a diferenciação de células HCT-116, e que essa quinase participa do processo de polaridade deste tipo celular.

E-mail: jmorgado@inca.gov.br 


\title{
Estudo de variações no promotor e 5'UTR de BRCA1
}

\author{
Fernandes $\mathrm{LR}^{1,2}$, Moreira MAM'1 da Costa ECB ${ }^{3}$ \\ ' Divisão de Genética, INCA \\ ${ }^{2}$ Universidade Federal do Estado do Rio de Janeiro - UNIRIO \\ ${ }^{3}$ Universidade Federal do Rio de Janeiro - UFRJ
}

Introdução: No Brasil, o câncer se apresenta como uma expressiva causa de mortalidade. O câncer da mama feminino é o segundo tipo de câncer mais incidente na população geral e o de maior incidência na população feminina. Estudos da American Society of Clinical Oncology (ASCO) mostram que, pelo menos, 5 a 10\% dos casos de câncer da mama e/ou ovário apresentam um padrão monogênico de transmissão, caracterizando a chamada síndrome de predisposição ao câncer da mama e/ou ovário. Em aproximadamente $2 / 3$ destas famílias, mutaçōes na região codificante nos genes $B R C A 1$ e $B R C A 2$ podem ser identificadas, as quais são herdadas de forma autossômica dominante. A região promotora de $B R C A 1$ apresenta dois éxons alternativos, $1 \mathrm{~A}$ e $1 \mathrm{~B}$, cada um com seu próprio promotor, a e b, respectivamente. O promotor apresenta maior atividade transcricional para o gene $B R C A 1$ e é bidirecional, regulando também a expressão de $N B R 2$, que é um gene de função desconhecida. No promotor $\alpha$, são observados a seqüência iniciadora de transcrição CCAAT box, mais três sítios de ligação para fatores de transcrição, além de 11 sítios CpG que podem ser metilados. O promotor $\beta$ possui uma atividade cerca de 150 vezes menor do que o $\alpha$, podendo ser modulado por elementos localizados no promotor $\alpha$ e pelo motivo alternativo de ligação para receptor de estrogênio (ERE), localizado no éxon $1 \mathrm{~B}$. Isto sugere que a transcrição de $B R C A 1$ pode ser co-regulada pelos dois promotores e pelo estrogênio. Os éxons $1 \mathrm{~A}$ e $1 \mathrm{~B}$ transcrevem duas regiōes não traduzidas chamadas 5'UTR-a e 5'UTR-b, respectivamente. O transcrito contendo 5'UTR-a é expresso, tanto em tecido mamário normal quanto tumoral, enquanto o 5'UTR-b é expresso apenas em tecido mamário tumoral. A região 5'UTR-b forma uma forte estrutura secundária composta de quatro módulos bastante estáveis que interferem no percurso do ribossomo, contribuindo para a menor tradução desse transcrito em relação ao transcrito contendo 5'UTR-a, que forma uma estrutura secundária menos estável. Uma alteração no éxon 1B pode mudar a estrutura secundária do transcrito contendo 5'UTR-b, alterando o nível de expressão da proteína BRCA1. Até o momento não foram descritas alterações na região promotora de BRCA1 (a não ser deleçōes de grandes trechos envolvendo o promotor) que possam estar relacionadas ao desenvolvimento de tumores hereditários. Objetivos: Avaliar se as mutaçôes pontuais e SNP detectadas nos promotores $\alpha$ e $\beta$ e no éxon 1B (5'UTR-b) do gene BRCA1, em pacientes selecionados com câncer da mama e/ou ovário hereditários do INCA, podem alterar o nível de transcrição e tradução do RNAm de BRCA1. Métodos: Para deteç̧ão das variações na região promotora de BRCA1, foram utilizadas as técnicas de SSCP, clonagem e seqüenciamento. As variações encontradas estão sendo clonadas em vetores de expressão para transfecção na linhagem celular MCF7, derivada de carcinoma mamário. Resultados: Foram identificados dois pacientes que carreiam a mesma alteração pontual (SNP-g3800C > T [GenBank L78833]), dois pacientes com alterações não descritas no éxon 1B SNP-g3988A>C e g3777G $>A$, sendo que, neste segundo caso, localiza-se dentro do motivo de ligação para receptores de estrogênio (ERE) e um paciente com alterações no promotor $\alpha(\mathrm{g} 3292 \mathrm{~T}>\mathrm{C})$, promotor $\beta(\mathrm{g} 3593 \mathrm{G}>\mathrm{A})$ e éxon $1 \mathrm{~B}(\mathrm{~g} 3800 \mathrm{C}>\mathrm{T})$. Os clones contendo as alteraçōes g3777G $>$ A e g3800C $>$ T, assim como clones com as variantes padrão foram selecionados e inseridos em um vetor de expressão (pEGFP-N1) para o prosseguimento do estudo. Discussão: Analisando as variações na 5'UTR-b (SNP$3800 \mathrm{C}>\mathrm{T}$ e g3777G $>\mathrm{A}$ ), observamos que as mesmas encontram-se numa região que contribui para a estabilidade da estrutura secundária do RNAm e por isso suspeitamos que essas variações podem desestabilizar a estrutura e promover uma alteração no nível de expressão de BRCA1. A variante g3777G $>$ A está dentro do motivo alternativo de ligação para receptores de estrogênio (ERE). O estrogênio, envolvido na modulação natural da diferenciação e crescimento do epitélio mamário, foi associado ao aumento e diminuição dos níveis de expressão do gene BRCA1 
e ao grau de agressividade dos tumores. Foram construídos plasmídeos recombinantes para avaliar a influência destas variaçôes na expressão do gene $B R C A 1$. A obtenção dos clones em vetor de expressão apropriado foi padronizada de forma a ser aplicada no estudo das alteraçóes observadas nos promotores (g3292T>C e g3593G>A), que poderiam estar associadas ao aumento do risco de câncer da mama hereditário.

Financiamento: INCA-Ministério da Saúde, FAPERJ, CNPq. E-mail:miguelm@inca.gov.br 


\title{
Genotipagem do papilomavírus humano (HPV) em amostras cervicais de mulheres do estado do Rio de Janeiro
}

\author{
Rabelo $\mathrm{E}^{1,2}$, Oliveira $\mathrm{M}^{2}$, Moreira $\mathrm{MAM}^{2}$ \\ 1 Universidade do Estado do Rio de Janeiro, Instituto de Câncer \\ ${ }^{2}$ Instituto Nacional de Câncer/INCA
}

\begin{abstract}
A infecção por papilomavírus humano (HPV) é o maior fator de risco para o desenvolvimento do câncer de colo do útero. No entanto, o câncer de colo do útero é considerado uma neoplasia que pode ser prevenida, uma vez que os tumores têm uma progressão relativamente lenta e existe uma forma simples e relativamente eficiente de detecção das lesóes precursoras. Os tipos de HPV que infectam a região genital são subdivididos (baseados no potencial oncogênico dos genótipos) em baixo risco, associados a lesões na região genital; e alto risco, freqüentemente associados ao câncer de colo do útero. Genótipos de HPV de alto risco interferem na regulação normal do ciclo celular, podendo-se integrar no ADN de células hospedeiras inativando os produtos dos genes supressores de tumor, p53 e Rb. O objetivo deste estudo é caracterizar os tipos virais de HPV em cerca de 400 amostras positivas para a presença de HPV utilizadas previamente para padronização de protocolo de detecção por captura-híbrida, cedidas pela Seção Integrada de Tecnologia em Citopatologia (SITEC), da Divisão de Patologia (DIPAT), do Instituto Nacional de Câncer (INCA). A partir destas amostras, o DNA total foi isolado e utilizado para amplificação por PCR. Utilizamos para controle da qualidade do DNA isolado a amplificação com primers para o gene BetaGlobina. Para detecção do genoma viral os primers MY09 e MY11, amplificando um fragmento de 450pb, e GP05 e GP06, que amplificam uma região interna ao fragmento anterior de 250pb (utilizados para PCR "em ninho"). Alternativamente, também foram utilizados os primers L1C1 e L2C2 que amplificam outra região do DNA viral de aproximadamente $300 \mathrm{pb}$. Os fragmentos amplificados para o DNA viral estão sendo seqüenciados para caracterização do tipo de vírus presente. Até o momento foram isolados os DNA de 164 amostras. Quarenta e quatro foram testadas para amplificação de beta-globina e em seis delas não obtivemos amplificação. Nove amostras foram positivas para amplificação com os primers GP05/GP06. Quatro foram positivos para amplificação com os primers MY09/MY11. Cinco amostras foram positivas para amplificação com os primers LC1/LC2. Foram seqüenciados os produtos de três amplificações e foram identificados os tipos virais 16, 16 ou 35 e 53, a partir de comparaçôes com bancos de dados de seqüências.
\end{abstract}

E-mail:miguelm@inca.gov.br 


\title{
Avaliação da presença de retículo endoplasmático em fagossomos de Leishmania Amazonensis
}

\author{
Souza NCC ${ }^{1,2}$, Benjamin $\mathrm{A}^{1,3}$, Bonomo $\mathrm{A}^{1,2}$ \\ 'Laboratório de Medicina Experimental - CPQ - INCA \\ ${ }^{2}$ Instituto de Microbiologia Prof. Paulo de Góes - UFRJ \\ ${ }^{3}$ Pós-graduação em Ciências Morfológicas - ICB - UFRJ
}

A leishmaniose é uma doença causada por protozoários do gênero Leishmania e afeta milhões de pessoas em áreas tropicais e subtropicais do mundo. A espécie L. amazonensis é o agente causador de leishmanioses cutâneas do Novo Mundo. Em seu estágio amastigota, são parasitas intracelulares obrigatórios e se multiplicam no interior de vacúolos parasitóforos dos macrófagos, sua principal célula hospedeira. Estes microorganismos - na "via clássica" de apresentação de antígenos - por serem antígenos exógenos, são apresentados às células T CD4+ por moléculas do complexo de histocompatibilidade principal (MHC) de classe II. Por outro lado, antígenos endógenos são apresentados às células $\mathrm{T} \mathrm{CD}^{+}$por moléculas $\mathrm{MHC}$ de classe I. Porém, vários estudos mostram a apresentação de peptídeos derivados de antígenos exógenos para células T CD8+. Este processo que denomina-se "apresentação cruzada" pode ser explicado pela associação do retículo endoplasmático (RE) ao fagossomo formado durante o englobamento do antígeno. É nesta organela que se encontra a maquinaria necessária para apresentação via MHC de classe I, como as moléculas TAP (Transporter Associated With Antigen Processing), tapasina, MHC I, calnexina, SEC61 e o complexo enzimático proteassomo. Entender melhor quais fenômenos estão envolvidos na apresentação cruzada de um patógeno extracelular é de extrema relevância, haja vista que a ativação de células TCD8 ${ }^{+}$é uma etapa importante na resolução de infecçōes causadas por Leishmania. Dados iniciais do nosso grupo mostram, através de microscopia confocal, positividade para TAP, SEC61, proteassomo e calnexina em fagossomos de macrófagos J774 que fagocitaram microesferas de látex e correlação entre a quantidade de micro-esferas fagocitadas e ativação de células T CD8 ${ }^{+}$. Perguntamos se isto também é verdade na infecção por Leishmania, ou seja, se a carga parasitária, ou a "quantidade de infecção" é determinante para possibilitar a apresentação cruzada e conseqüente ativação de células $\mathrm{T} \mathrm{CD}^{+}$específicas para $L$. amazonensis. Inicialmente, estamos analisando a relação entre a utilização da membrana de RE e a infecção in vitro por microscopia confocal.

Financiamento: CNPq, FAPERJ, Swiss Bridge Foundation. E-mail:abonomo@inca.gov.br 


\title{
Correlação dos polimorfismos gênicos da família GST com suscetibilidade à leucemia linfoblástica aguda da infância
}

\author{
Faccion RS, Briggs B, Kwee JK, Pombo de Oliveira MS, Maia RC, Klumb CE \\ Hematologia Celular e Molecular, Serviço de Hematologia, Hospital do Câncer I/INCA
}

Introdução: As enzimas do sistema glutationa-S transferase (GST) são enzimas fisiologicamente envolvidas na fase II da detoxificação de agentes xenobióticos e atuam no metabolismo de diversos quimioterápicos empregados no tratamento do câncer. Certos membros desta superfamília possuem polimorfismos genéticos que estão associados com maior risco de desenvolvimento de algumas neoplasias malignas, dentre elas câncer de pulmão, de vesícula biliar, câncer cervical, carcinoma de nasofaringe, câncer de próstata, e outros. Diversos estudos apontaram determinados polimorfismos como fatores de risco para o desenvolvimento de leucemia linfoblástica aguda (LLA). No entanto, esta associação não é um consenso entre os estudos relatados, e a literatura é escassa em estudos realizados no nosso meio. Objetivos: Estudar a freqüência dos genótipos da família glutationa-S-transferase GSTM1 e GSTT1 em indivíduos saudáveis e numa série de pacientes pediátricos com LLA, e sua associação com o risco de doença. Material e Métodos: O DNA de amostras de 70 pacientes foi extraído e os genótipos GSTM1 e GSTT1 foram determinados por PCR Multiplex. O gene constitutivo b-globina foi utilizado como controle de amplificação. Resultados: Até o momento, os genótipos GSTM1 e GSTT1 de 47 amostras foram determinados. Destas, 47\% apresentaram fenótipo GSTM1 null (não continham GSTM1), 17\% apresentaram fenótipo GSTT1 null, 6\% apresentaram fenótipo null para ambos os genes e 43\% apresentaram genótipos GSTM1 e GSTT1. Conclusão: $\mathrm{Na}$ fase atual, as amostras de pacientes com LLA estão sendo genotipadas. A avaliação dos genótipos de indivíduos controles será realizada em seguida. Após esta etapa, uma análise estatística apropriada será empregada para que uma possível associação entre os genótipos estudados e risco de LLA infantil possa ser avaliada. Este estudo contribuirá para que o impacto desses genótipos na etiopatogenia da LLA infantil em nosso meio seja melhor elucidado.

Financiamento: FINEP.

E-mail: hemato_hc@inca.gov.br 


\title{
Efeito do trióxido de arsênico e da doxorubicina na expressão da survivina em células leucêmicas de origem mielóide
}

\author{
Prazeres MF, Silva KL, Maia RC \\ Laboratório de Hematologia Celular e Molecular - Serviço de Hematologia - HCl/NCA
}

Introdução: Dentre as principais características do câncer estão as alteraçôes nas vias de indução da apoptose. Nas leucemias, a superexpressão de proteínas anti-apoptóticas é uma das importantes causas de falha no tratamento quimioterápico. Dentre as proteínas envolvidas na inibição da apoptose, as proteínas da família das IAP (proteínas inibidoras da apoptose) merecem destaque, pois são capazes de inibirem as caspases, proteases que desempenham papel central na execução da apoptose. A superexpressão da survivina, proteína pertencente à família das IAP, é considerada um fator de resistência ao tratamento quimioterápico em alguns tipos de leucemias, tornando-se factível a utilização de drogas que propiciam a diminuição da expressão dessa proteína. Objetivo: Analisar se fármacos, com diferentes mecanismos de ação como o trióxido de arsênico $\left(\mathrm{As}_{2} \mathrm{O}_{3}\right)$, e a doxorubicina (Doxo) são capazes de inibir a expressão da survivina nas linhagens de leucemia mielóide aguda (LMA) HL60 (LMA-M2), NB4 (LMA-M3), U937 (LMA-M5) e K562 (leucemia mielóide crônica em crise blástica - M6). Metodologia: A análise do efeito do $\mathrm{As}_{2} \mathrm{O}_{3}$ e da Doxo, na viabilidade celular, foi realizada através do ensaio de MTT. Para determinação da dose capaz de diminuir a viabilidade celular em $50 \%$ das células $\left(\mathrm{DL}_{50}\right)$, as linhagens foram incubadas por 24, 48 e 72 horas na presença ou não de $\mathrm{As}_{2} \mathrm{O}_{3}$ ou Doxo em concentraçôes que variaram de $0,5 \mu \mathrm{M}$ a $10 \mu \mathrm{M}$. Após a obtenção das $\mathrm{DL}_{50}$, foram feitos ensaios de marcação com anexina $\mathrm{V}$ e iodeto de propídio para análise da indução de apoptose por citometria de fluxo, e Western blot para análise da expressão da survivina. Resultados: A sensibilidade ao $\mathrm{As}_{2} \mathrm{O}_{3}$ e à Doxo variou entre as linhagens leucêmicas, sendo a linhagem HL60 a mais sensível seguida da NB4, U937 e K562 para as duas drogas testadas. As concentrações das DL $_{50}$ obtidas para o $\mathrm{As}_{2} \mathrm{O}_{3}$ foram de $2 \mu \mathrm{M}, 3 \mu \mathrm{M}, 4 \mu \mathrm{M}$ e $5 \mu \mathrm{M}$ em 24 horas de cultivo para HL60, NB4, U937 e K562, respectivamente, enquanto que, para a Doxo, as concentraçôes das DL50 foram de $10 \mu \mathrm{M}$ em 24 horas para HL60 e NB4, $5 \mu \mathrm{M}$ em 48 horas para K562 e $1 \mu \mathrm{M}$ em 72 horas para U937. Utilizando-se as concentrações da $\mathrm{DL}_{50}$ nos tempos estabelecidos, a marcação com anexina $\mathrm{V}$ e iodeto de propídio mostrou que o As2 $\mathrm{O} 3$ foi capaz de induzir apoptose em todas as linhagens testadas: HL60 (50\%), NB4 (22,1\%), K562 (32,7\%) e U937 (21,84\%). Também, foi possível observar que a Doxo induziu apoptose nas linhagens HL60 (86,8\%), NB4 (45,7\%), U937 (35,7\%), mas não nas células K562 (2,2\%). De forma interessante, $\mathrm{As}_{2} \mathrm{O}_{3}$ e Doxo diminuíram a expressão da survivina em células HL60 em cerca de 72,7 e $69,2 \%$, respectivamente, quando a $\mathrm{DL}_{50}$ foi utilizada. Entretanto, na linhagem NB4, houve um aumento de 50 e 70\%, respectivamente, na expressão dessa proteína. Nas linhagens K562 e U937, não houve alteração significativa na intensidade de expressão da survivina. Discussão e Conclusão: Neste trabalho, tivemos como objetivo analisar o papel da survivina na resistência ou não aos quimioterápicos $\mathrm{As}_{2} \mathrm{O}_{3}$ e Doxo em células de linhagens leucêmicas de origem mielóide. Tais drogas foram escolhidas por possuírem diferentes mecanismos de ação, porém, capazes de induzirem apoptose através da ativação das caspases. A linhagem HL60 mostrou ser a mais sensível às drogas utilizadas dentre as linhagens estudadas. Tal sensibilidade pode ser devido à capacidade de diminuição da expressão de survivina nessas células, sugerindo que, nesse tipo de leucemia, a survivina poderia ser considerada um alvo terapêutico e que os fármacos em questão são capazes de diminuir a resistência. $\mathrm{O}$ resultado oposto foi observado na linhagem NB4. Ambas as drogas utilizadas aumentaram a expressão da survivina. Porém, esse aumento não se correlacionou com a resistência pois, dentre as linhagens estudas, a NB4 mostrou ser a segunda mais sensível. Sabe-se que a survivina, em células normais, tem sua expressão aumentada durante a fase 
G2/M, pois esta participa na formação de fuso acromático. Entretanto, células tumorais possuem altos níveis de expressão da survivina independente da fase do ciclo celular. Uma hipótese seria de que as drogas utilizadas estariam levando as células NB4 a uma parada no ciclo celular, aumentando a população de células na fase G2/M e, por isso, ocorrendo o aumento da expressão da survivina. Outra hipótese seria de que as drogas utilizadas estariam induzindo resistência nas células NB4 remanescentes ao aumentarem a expressão dessa proteína. Entretanto, a ação do $\mathrm{As}_{2} \mathrm{O}_{3}$ e da Doxo sobre a survivina parece ser tipo celular-específica. Além disso, proteínas reguladoras da apoptose como caspases, Smac (inibidora da survivina) e outras IAP podem estar envolvidas na resistência a esses quimioterápicos nessas linhagens. Portanto, estudos mais aprofundados são necessários para identificarmos o real papel da survivina na resistência à apoptose em células de LMA.

Apoio Financeiro: Swiss Bridge Foudation, FINEP, CNPq, CAPES.

E-mail: hemato_hc@inca.gov.br 


\title{
Transporte do cálcio por isoformas da $\mathrm{Ca}^{2+}$ - ATPase em leucemias
}

\author{
Luque DG, Gavinho-Vianna FA, Vasconcelos FC, Rumjanek VM, Maia RC \\ Laboratório de Hematologia Celular e Molecular, Serviço de Hematologia, HCI/INCA
}

Introdução: A resistência a múltiplas drogas (MDR) está relacionada com a expressão da glicoproteína P (Pgp), proteína relacionada à MDR $(\mathrm{MRP})$ e breast cancer releated protein (BCRP). A interação entre MDR e a família de proteínas chamadas SERCA (sarco/reticulum $\mathrm{CA}^{2+}$-ATPases), que transportam cálcio do citoplasma para o retículo sarco/endoplasmático, foi observada em uma linhagem leucêmica resistente, exibindo fenótipo MDR mediado pela expressão da Pgp (K562-Lucena). A SERCA não foi inibida pela Tapsigargina (TG), seu inibidor específico, ao contrário da linhagem parental K562 Pgp negativa. Não há estudos semelhantes em amostras de pacientes leucêmicos. Objetivo: Analisar o perfil de mobilização de cálcio em amostras de células de pacientes leucêmicos com e sem o fenótipo MDR. Materiais e métodos: Foram utilizadas amostras de sangue periférico ou de medula óssea de 22 pacientes leucêmicos: 6 de LMC (leucemia mielóide crônica), 10 de LMA (leucemia mielóide aguda), 2 de LLA (leucemia linfóide aguda) e 4 de LLC (leucemia linfóide crônica). Como controle, foram utilizadas células mononucleares do sangue de indivíduos normais. O perfil de mobilização de cálcio foi determinado por fluorescência, utilizando Fura 2-AM. A expressão e a atividade das proteínas MDR foram analisadas por citometria. Resultados: As amostras de LLC e LLA exibiram perfis de mobilização de cálcio semelhantes aos dos indivíduos normais, enquanto que os perfis de mobilização de cálcio das amostras de LMC e LMA mantiveram-se iguais entre si, mas diferentes daqueles observados em indivíduos normais. Nenhuma amostra leucêmica apresentou resistência à ação da TG. Dezesseis, de 22 amostras, eram Pgp +, 11/22 MRP + e 1/22 BCRP +. Dezenove amostras exibiram atividade MDR. Discussão e conclusão: Nas células dos pacientes (diferente das linhagens), a presença do fenótipo MDR não induziu resistência à ação inibidora da TG. O acúmulo de cálcio é o resultado não só da mobilização dos estoques internos de cálcio como da entrada e saída de cálcio extracelular e o tamponamento de cálcio para as mitocôndrias. Conforme foi observado em nosso trabalho, diversos tipos celulares podem apresentar diversos níveis de cálcio intracelular após estímulo como resultado dos mecanismos operantes nestas células. Para entendermos melhor os padrões de acúmulo de cálcio nas diversas leucemias, serão necessários experimentos que estudarão o efeito do cálcio extracelular e a análise da ação de inibidores da calmodulina na inibição da $\mathrm{Ca}^{2+}$-ATPase de membrana plasmática.

Financiamento: PRONEX, FAPERJ. E-mail: hemato_hc@inca.gov.br 


\title{
Estudo do perfil inflamatório da doença enxerto-contra- hospedeiro aguda
}

\author{
Du Rocher BAS; Diamond HR; Campos MM; Gomes BE; Wagner-Souza K; Lira CCP; Almeida-Oliveira A; Amado DS; Abdelhay E; Ornellas MH \\ Laboratório do CEMO - INCA
}

Introdução: A infusão de células-tronco hematopoéticas alogeneicas (ICTH) tornou-se o tratamento de escolha para inúmeras doenças hematológicas. Embora sua importância seja evidente, uma grande limitação é a alta incidência da doença enxerto-contra-hospedeiro $(\mathrm{DECH})$ nos transplantes alogeneicos levando a uma alta taxa de morbi-mortalidade. A DECH é caracterizada como uma doença inflamatória na qual o enxerto imunocompetente reage contra o hospedeiro que se encontra imunossuprimido e extremamente inflamado em decorrência do regime de condicionamento. Assim, após a ICTH, as células T do doador encontram um micro-ambiente favorável (inflamado e com antígenos não próprios) à sua ativação e iniciam uma resposta imune contra o hospedeiro levando à injúria tecidual. Assim, as citocinas desenvolvem um papel crucial, já que elas são um dos fatores responsáveis por fornecer e manter o estímulo necessário à ativação das células $\mathrm{T}$ e por possibilitar a migração destas células para os órgãos alvos. Objetivos: I) Quantificar as concentrações séricas de determinadas citocinas antes, durante e após a ICTH visando à obtenção de dados e/ou padrões que possam predizer o grau da DECHa ou a evolução no pós-ICTH. II) Avaliar o perfil TH1/Th2 destes pacientes. Metodologia: Foram separados plasmas de pacientes que se submeteram à ICTH mediante a concordância destes em participar desta pesquisa. As amostras obtidas nos dias D-8, D0, D+15, D+30, D+45 e D+90 foram congeladas a $-80^{\circ} \mathrm{C}$ até o momento do experimento. Os níveis das citocinas IL-2, IL-4, IL-5, IL-10, TNF- $\alpha$ e IFN- $\gamma$ foram medidos empregando a técnica Human Th1/Th2 Cytokine Cytometric Bead Array por citometria de fluxo. Resultados: Entre março/2005 e junho/2006, foram estudados 14 pacientes. Observou-se um aumento das citocinas IL-5, IL-10 e IFN-g no D+15. A partir desta data, foi observado um decréscimo progressivo dos níveis de IFN-g que se mantiveram em declínio até o D+90. A IL-5, durante todo o período, oscilou e a IL-10 diminuiu até o D+30, mantendo-se constante. Nos pacientes com DECHa, foram observados níveis aumentados de IFN-g quando comparados ao paciente que não desenvolveu a doença. Neste, observou-se que os níveis de IL-4, IL-5, IL-10 mantiveram-se aumentados. Apesar da pequena amostra, estes dados sugerem que o equilíbrio entre as citocinas pró e anti-inflamatórias pode predizer o desenvolvimento da DECHa e permitir um melhor monitoramento em prol do benefício para o paciente.

E-mail: eabdelhay@inca.gov.br 


\title{
Caracterização imunofenotípica de leucemia linfoblástica aguda (LLA) comprometida com a linhagem B
}

\author{
Amado DS; Diamond HR; Du Rocher BAS; Almeida-0liveira A; Gomes BE; Wagner-Souza K; Lira CCP; Campos MM; Souza MHFO
}

Imunologia do CEMO/INCA

\begin{abstract}
A leucemia linfoblástica aguda (LLA) é caracterizada por um acúmulo excessivo de linfoblastos dentro do espaço medular, decorrente de uma proliferação clonal incontrolada de precursores linfóides que perderam a capacidade de diferenciação. A doença é heterogênea quanto a aspectos morfológicos, fenotípicos, citogenéticos e clínicos. A imunofenotipagem permite a identificação de antígenos na membrana celular, no citoplasma ou mesmo intranuclear pela ligação com anticorpos monoclonais. O objetivo deste trabalho foi o estudo imunofenotípico de pacientes portadores de leucemia linfoblástica aguda comprometida com a linhagem $\mathrm{B}$, oriundos de entidades públicas do Rio de Janeiro, relacionando com dados da literatura. Foram estudados pacientes recém diagnosticados. Até a presente data, foram estudadas amostras de medula óssea ou sangue periférico de 31 pacientes, sendo 12 do sexo masculino e 19 do feminino. O anticorpo monoclonal CD19 estava presente em 93,5\% dos casos, o CD10 em $83,9 \%$, sendo a dupla positividade para CD10 e CD19 encontrada em 76,7\% dos casos. O anticorpo monoclonal CD22 esteve presente em 84,6\% das amostras analisadas e o CD20 em 33,3\%. Ocorreu alta incidência de CD34 e HLA-DR, que são marcadores de células mais indiferenciadas, a presença de marcadores aberrantes foi rara, apenas um paciente foi reativo ao $\mathrm{CD} 13$, um ao $\mathrm{CD} 7$ e quatro ao $\mathrm{CD} 33$. Neste estudo, houve a predominância do subtipo B precoce $(77,4 \%$ dos pacientes), caracterizado pela positividade brilhante do anticorpo monoclonal CD10 envolvendo grande percentual de células leucêmicas, que foi altamente freqüente em crianças de 1 a 9 anos, totalizando $45,2 \%$ dos casos. O subtipo pré-B foi observado em 16,1\% dos pacientes estudados, sendo mais freqüente em mulheres $(60 \%)$ e o subtipo pró-B teve uma incidência de $6,5 \%$, ocorrendo somente em duas crianças do sexo feminino, uma de 3 anos e outra de 4 anos. A ausência de pacientes com LLA B transicional e com LLA B madura pode ser justificada pela raridade dessa doença e pelo pequeno número amostral estudado. Os resultados obtidos através deste estudo estão de acordo com os dados da literatura.
\end{abstract}

E-mail:imuno@inca.gov.br 


\section{Estabelecimento de vetores retrovirais para análise do NFAT na diferenciação e proliferação celular}

Cruz ALC, Robbs BK, Viola JPB

Divisão de Biologia Celular/INCA

O fator nuclear de células $\mathrm{T}$ ativadas (nuclear factor of activated $T$ cells - NFAT) foi inicialmente descrito como sendo capaz de regular a expressão do gene IL-2 em células T Jurkat ativadas. Atualmente, cinco membros distintos constituem a família NFAT: NFAT1 (também conhecido como NFATp ou NFATc2), NFAT2 (NFATc ou NFATc1), NFAT3 (NFATc4), NFAT4 (NFATx ou NFATc3) e NFAT5 (TonE-BP). Os cinco membros dessa família compartilham uma região de ligação ao DNA altamente conservada e estruturalmente similar entre si. As proteínas NFAT1-4 são ativadas pela fosfatase calcineurina a partir de estímulos que aumentem os níveis intracelulares de cálcio. A calcineurina atua desfosforilando serinas em um domínio regulatório presente nestas proteínas, levando à sua translocação nuclear e a ativação de sua atividade transcripcional. Sítios de ligação para NFAT foram descritos em inúmeros genes incluindo citocinas IL-2, IL-4, IL-13, IFN- $\gamma$, TNF- $\alpha$, proteínas de superfície CD40L e FasL e outros genes envolvidos em proliferação, diferenciação e morte celular. Dados obtidos em camundongos knockout mostram que a deficiência da proteína NFAT1 gera um fenótipo hiperproliferativo, um aumento na produção de IL-4 e uma diminuição na produção de IFN-g, enquanto que a deficiência de NFAT2 causa uma redução dos níveis de IL-4 e da proliferação celular. Apesar destes resultados, ambas as proteínas são capazes de induzir a expressão das citocinas IL-4 e IFN-g em experimentos in vitro. Para entender este paradoxo, vetores retrovirais foram construídos contendo os genes NFAT1 e NFAT2 e suas formas constitutivamente ativas feitas com mutações de serinas da região regulatória para alaninas, simulando uma proteína desfosforilada. Esses vetores apresentam o gene repórter EGFP em duas situações: fusionado com o NFAT (vetor pLEGFP) ou separado deste por um sítio de entrada ribossomal interno (vetor pLIRES-EGFP). Após a etapa de construção, validaremos os vetores a partir de uma série de ensaios após a transfecção em linhagem 293T: western blot para confirmação da expressão de NFAT para análise de peso molecular e níveis de defosforilação; localização subcelular por microscopia de fluorescência e ensaio de transativação a partir de atividade de luciferase de um promotor contendo três regiōes consenso de ligação para NFAT. A validação desses vetores é uma etapa crucial para concretizar sua utilização em diversos projetos do laboratório, cujo objetivo final visa a elucidar o papel dos membros NFAT1 e NFAT2 no controle da proliferação e diferenciação celular no sistema imune.

E-mail: jpviola@inca.gov.br 


\title{
Caracterização do polimorfismo Ile655Val do gene ERBB2 em pacientes com câncer da mama
}

\author{
Indio-do-Brasil V, Vianna-Jorge $R$ \\ Divisão de Farmacologia, CPQ-INCA - Depto. de Farmacologia Básica e Clínica, ICB-UFRJ
}

Introdução: A proteína HER-2 é um receptor associado à tirosina-quinase, com estrutura similar à do receptor de fator de crescimento epitelial. A HER-2 está presente em aproximadamente um terço dos carcinomas primários da mama e sua expressão está associada a um mau prognóstico. A expressão de HER-2 aumenta parâmetros de resposta proliferativa e metastática em câncer da mama e induz resistência à terapia hormonal, paclitaxel e ao TNF- $\alpha$ (fator de necrose tumoral- $\alpha$ ). O gene ERBB2 (17q21), responsável pela codificação de HER-2, apresenta polimorfismo (Ile655Val) na região codificante do domínio trans-membrana e há controvérsias quanto à associação entre a presença do alelo variante $\mathrm{Val}^{655}$ e o maior risco de câncer da mama. A freqüência do alelo Val ${ }^{655}$ varia entre diferentes grupos étnicos e não há dados na literatura quanto à freqüência deste polimorfismo entre brasileiras. Objetivos: Desenvolver e validar metodologia para caracterizar os genótipos do polimorfismo Ile655Val do gene ERBB2 de pacientes com câncer da mama. Calcular a freqüência do alelo variante Val ${ }^{655}$, e estimar o número de indivíduos para um estudo caso-controle. Metodologia: Foram genotipadas 31 pacientes que apresentaram idade média de 50,8 anos ( $\mathrm{IC}_{95 \%}$ 47,7 - 53,9), e autoclassificadas como brancas (15), intermediárias (13) e negras (2), com diagnóstico de adenocarcinoma da mama invasivo (primário, operável e não metastático), após o término de quimioterapia neoadjuvante, adjuvante, cirurgia e/ou radioterapia realizadas no INCA - HC III, Rio de JaneiroRJ, com determinação de status HER-2 em biópsias tumoral. O DNA genômico foi extraído das amostras de sangue através do sistema "DNAzol" (Invitrogen Life Technologies, Carlsbad, EUA) e submetido a reações de PCR, baseadas no método já descrito por Xie et al. A avaliação da ocorrência do polimorfismo foi realizada com base no perfil de digestão do fragmento de PCR pela endonuclease específica BsmA I. As amostras, com indicativo de variação alélica, de acordo com o perfil de PCR-RFLP, foram submetidas a seqüenciamento automático.

Resultados e Discussões: Os perfis de separação eletroforética dos produtos digeridos conseguiram distinguir com clareza os homozigotos variantes dos selvagens e dos heterozigotos.

A distribuição dos diferentes genótipos das 31 pacientes com câncer da mama está representada abaixo.

Distribuição dos genótipos ERBB2 em pacientes com câncer da mama

\begin{tabular}{c|c|c|c|c}
\hline Genótipo & $\mathrm{N}$ & Brancas & intermediárias & negras \\
\hline $\mathrm{lle} / \mathrm{lle}$ & 27 & 12 & 12 & 2 \\
\hline $\mathrm{lle} / \mathrm{Val}$ & 3 & 2 & 1 & 0 \\
\hline $\mathrm{Val} / \mathrm{Val}$ & 1 & 1 & 0 & 0 \\
\hline
\end{tabular}

A freqüência do alelo variante $\mathrm{Val}^{655}$ foi de $0,08\left(\mathrm{IC}_{95 \%} 0,03-0,18\right)$. Esse valor está compreendido entre as freqüências observadas para populações africanas e afro-americanas $(0,01-0,09)$ e abaixo das freqüências observadas entre pacientes européias e euro-americanas $(0,20$ - 0,26). O pequeno tamanho de nossa amostra, associado à grande miscigenação da população brasileira, limita a comparação entre os diferentes resultados de freqüência já descritos na literatura. Com base nestes resultados preliminares de freqüência, podemos estimar que, para a avaliação de associação entre o alelo variante $\mathrm{Val}^{655}$ e o risco de câncer da mama na população brasileira, seria necessário realizar um estudo caso-controle com pelo menos 300 indivíduos em cada grupo. 


\section{Caracterização do papel do fator de transcrição NFAT1 na progressão do ciclo celular e na tumorigênese}

Bastos NC, Carvalho LDS, Viola JPB

Grupo de Regulação Gênica, Divisão de Biologia Celular, Coordenação de Pesquisa, INCA.

A família de fatores de transcrição NFAT (Nuclear Factor of Activated T cells) foi inicialmente descrita durante a ativação e diferenciação de linfócitos T. Diversos trabalhos descreveram as proteínas NFAT como reguladoras da ativação de células do sistema imune e da expressão de seus mediadores imunológicos. Sítios de ligação para as proteínas NFAT estão presentes nas regiōes promotoras de diversos genes de citocinas, e de moléculas de superfície. No entanto, trabalhos recentes vêm demonstrando que proteínas NFAT estão presentes em uma grande variedade de tipos celulares e tecidos não relacionados ao sistema imune. De fato, esses fatores de transcrição têm sido implicados na regulação de genes envolvidos com o desenvolvimento, a proliferação, a diferenciação, a angiogênese e possivelmente com a tumorigênese. $\mathrm{O}$ objetivo deste trabalho é caracterizar o papel do fator de transcrição NFAT1 na progressão normal do ciclo celular e na tumorigênese. Para alcançar esses objetivos, foi construída uma linhagem celular que apresenta expressão condicional da proteína NFAT1 induzida através da adição de tetraciclina (CHO-NFAT1). A análise dessa linhagem celular comprovou que a proteína NFAT1 mantém suas propriedades funcionais, sendo ativada e translocada para o núcleo através de um estímulo de cálcio, e tendo sua atividade bloqueada pela droga imunossupressora ciclosporina A. Ensaios de proliferação por incorporação de timidina tritiada demonstraram que as células que expressam NFAT1 proliferam menos do que as células controle (sem NFAT1). A marcação com iodeto de propídio demonstrou um atraso na entrada em fase $S$ do ciclo celular pelas células que expressam NFAT1 quando comparadas às células controle. O inóculo subcutâneo da linhagem celular CHO-NFAT1 em camundongos BALBc nude/nude demonstrou que o crescimento tumoral in vivo é significativamente reduzido quando a expressão de NFAT1 é induzida pelo tratamento com tetraciclina. Ensaios preliminares da expressão de genes do ciclo celular apontam para uma inibição da expressão de ciclinas durante a expressão condicional de NFAT1. O conjunto desses resultados pretende indicar a participação da proteína NFAT1 durante a progressão do ciclo celular e um possível papel supressor de tumor in vivo.

Financiamentos: CNPq, Furnas, Fogarty/NIH, ICGEB. E-mail: jpviola@inca.gov.br 